BNL-94911-2011-IR

\title{
Self-degradable Slag/Class F Fly Ash-Blend Cements
}

\author{
Toshifumi Sugama, John Warren, and Thomas Butcher, \\ Brookhaven National Laboratory; \\ Lance Brothers, Halliburton; \\ Daniel Bour, AltaRock Energy, Inc.
}

March 2011

\author{
Sustainable Energy Technologies Department \\ Brookhaven National Laboratory
}

\section{U.S. Department of Energy \\ [DOE Office of Energy Efficiency and Renewable Energy], [DOE Office of Geothermal Technologies]}




\section{DISCLAIMER}

This report was prepared as an account of work sponsored by an agency of the United States Government. Neither the United States Government nor any agency thereof, nor any of their employees, nor any of their contractors, subcontractors, or their employees, makes any warranty, express or implied, or assumes any legal liability or responsibility for the accuracy, completeness, or any third party's use or the results of such use of any information, apparatus, product, or process disclosed, or represents that its use would not infringe privately owned rights. Reference herein to any specific commercial product, process, or service by trade name, trademark, manufacturer, or otherwise, does not necessarily constitute or imply its endorsement, recommendation, or favoring by the United States Government or any agency thereof or its contractors or subcontractors. The views and opinions of authors expressed herein do not necessarily state or reflect those of the United States Government or any agency thereof. 
Self-degradable Slag/Class F Fly Ash-Blend Cements

Prepared for

The U.S. Department of Energy

Energy Efficiency and Renewable Energy

Geothermal Technologies Program

1000 Independence Avenue SW

Washington, D.C. 20585

Prepared by

Toshifumi Sugama, John Warren, and Thomas Butcher

Sustainable Energy Technologies Department

Brookhaven National Laboratory

Upton, NY 11973-5000

Lance Brothers

Halliburton

2600 S. $2^{\text {nd }}$ Street

P.O. Drawer 1431

Duncan, OK 73536-0442

Daniel Bour

AltaRock Energy, Inc.

7900 E. Green Lake Drive N., Suite 202

Seattle, WA 98103-4818

March 2011

Notice: This manuscript has been authored by employee of Brookhaven Science Associates, LLC under Contract No. DE-AC02-98CH 10886 with the U.S.

Department of Energy. The publisher by accepting the manuscript for publication acknowledges that the United States Government retains a non-exclusive, paid-up, irrevocable, world-wide license to publish or reproduce the published form of this manuscript, or allow others to do so, for the United States Government purposes. 


\section{Abstract}

Self-degradable slag/Class F fly ash blend pozzolana cements were formulated, assuming that they might serve well as alternative temporary fracture sealers in Enhanced Geothermal System (EGS) wells operating at temperatures of $\geq 200^{\circ} \mathrm{C}$. Two candidate formulas were screened based upon material criteria including an initial setting time $\geq 60$ min at $85^{\circ} \mathrm{C}$, compressive strength $\geq 2000$ psi for a $200^{\circ} \mathrm{C}$ autoclaved specimen, and the extent of self-degradation of cement heated at $\geq 200^{\circ} \mathrm{C}$ for it was contacted with water. The first screened dry mix formula consisted of $76.5 \mathrm{wt} \%$ slag-19.0 wt\% Class F fly ash$3.8 \mathrm{wt} \%$ sodium silicate as alkali activator, and $0.7 \mathrm{wt} \%$ carboxymethyl cellulose (CMC) as the self-degradation promoting additive, and second formula comprised of $57.3 \mathrm{wt} \%$ slag, $38.2 \mathrm{wt} \%$ Class $\mathrm{F}$ fly ash, $3.8 \mathrm{wt} \%$ sodium silicate, and $0.7 \mathrm{wt} \% \mathrm{CMC}$. After mixing with water and autoclaving it at $200^{\circ} \mathrm{C}$, the aluminum-substituted $1.1 \mathrm{~nm}$ tobermorite crystal phase was identified as hydrothermal reaction product responsible for the development of a compressive strength of 5983 psi. The $200^{\circ} \mathrm{C}$-autoclaved cement made with the latter formula had the combined phases of tobermorite as its major reaction product and amorphous geopolymer as its minor one providing a compressive strength of 5271 psi. Sodium hydroxide derived from the hydrolysis of sodium silicate activator not only initiated the pozzolanic reaction of slag and fly ash, but also played an important role in generating in-situ exothermic heat that significantly contributed to promoting selfdegradation of cementitious sealers. The source of this exothermic heat was the interactions between sodium hydroxide, and gaseous $\mathrm{CO}_{2}$ and $\mathrm{CH}_{3} \mathrm{COOH}$ by-products generated from thermal decomposition of $\mathrm{CMC}$ at $\geq 200^{\circ} \mathrm{C}$ in an aqueous medium. Thus, the magnitude of this self-degradation depended on the exothermic temperature evolved in the sealer; a higher temperature led to a sever disintegration of sealer. The exothermic temperature was controlled by the extent of thermal decomposition of CMC, demonstrating that $\mathrm{CMC}$ decomposed at higher temperature emitted more gaseous reactants. Hence, such large emission enhanced the evolution of $\underline{\text { in-situ }}$ exothermic heat. In contrast, the excessive formation of geopolymer phase due to more incorporation of Class F fly ash into this cementitious system affected its ability to self-degrade, reflecting that there was no self-degradation. The geopolymer was formed by hydrothermal reactions between sodium hydroxide from sodium silicate and mullite in Class F fly ash. 
Thus, the major reason why geopolymer-based cementitiuos sealers did not degrade after heated sealers came in contact with water was their lack of free sodium hydroxide.

\section{Introduction}

In our ongoing project aimed at developing temporary cementitious sealing materials for enhanced geothermal system (EGS) wells, BNL succeeded in formulating the selfdegradable sealer made with five starting materials: Granulated blast-furnace slag; Class C fly ash; sodium silicate as an alkali activator; sodium carboxymethyl cellulose (CMC) as a self-degradation promoting additive, and water [1]. The formulated cementitious sealer had the following properties before its self-degradation occurred; initial- and finalsetting times of $\sim 120$ and $\sim 180$ min at $85^{\circ} \mathrm{C} ; 2187 \mathrm{psi}$ compressive strength with a porosity of $36.5 \%$ after autoclaving at $200^{\circ} \mathrm{C}$; and 1825 to 1375 psi compressive strength with 51.2 to $55.0 \%$ porosity after the autoclaved sealers were heated between $200^{\circ} \mathrm{C}$ and $300^{\circ} \mathrm{C}$. In addition, the developed sealer was formulated without the use of any Ordinary Portland Cement (OPC), which causes the emission of 0.873 metric ton of $\mathrm{CO}_{2}$ [2] and a great deal of mercury [3], while manufacturing one ton of OPC, strongly suggesting that our cementitious sealer eliminates this carbon footprints and alleviates the environmental impact. Similarly, our usage of slag and fly ash resources has beneficial environmental effects. According to U.S. Geological Survey, in 2000, U.S steel industries generated 8.9 million tons of slag as wastes and by-products [4], and in 2009, 5.7 million tons of fly ash by-products were yielded from U.S. coal combustion power plants [5]. Of these amounts, 5.1 million tons slag and 2.2 million tons fly ash were recycled into industrial products. Thus, this abundant resource of these by-products as the starting materials of this cementitious sealer assures the local availability across the U.S.A.

The self-degradation of sealer occurred, when the autoclaved sealer heated at temperatures of $\geq 200^{\circ} \mathrm{C}$ came in contact with water. We interpreted the mechanism of this water-initiated self-degradation as resulting from the in-situ exothermic reactions between the reactants yielded from the hydrolysis of sodium silicate activator and the thermal degradation of the CMC. The magnitude of self-degradation depended on the $\mathrm{CMC}$ content; its effective content in promising degradation was $\geq 0.7 \%$. However, for 
Class G well cement, CMC did not offer as effective as that of our cementitius system; no self-degradation was noted from CMC-containing Class G well cement.

In this progress period, our focus concentrated on formulating and characterizing CMCcontaining slag/Class F fly ash-based self-degradable cement as an alternative temporary fracture sealer for fractures in EGS wells. Then, we compared the physicochemical properties of our candidate sealers with those of existing slag/Class C fly ash-based sealing system. The parameters considered were the initial-setting time at $85^{\circ} \mathrm{C}$, the compressive strength and porosity in the range of $200^{\circ} \mathrm{C}$ to $300^{\circ} \mathrm{C}$, the crystalline and amorphous phases responsible for strengthening the sealer, and the exothermic temperature promoting self-degradation of heated sealer after it contacted with water.

\section{Experimental Procedure}

Two industrial by-products with pozzolanic properties, granulated blast-furnace slag under trade name "New Cem," and Class F fly ash, were used as the hydraulic pozzolana cement. The slag was supplied from Lafarge North America, and fly ash was obtained from Boral Material Technologies, Inc. Table 1 lists their chemical constitutions. A sodium silicate granular powder under trade name "Metos Bead 2048," supplied by The PQ Corporation, was used as the alkali activator of these pozzolana cements; its chemical composition was 50.5 mol. wt $\% \mathrm{Na}_{2} \mathrm{O}$ and $46.6 \mathrm{~mol}$. wt $\% \mathrm{SiO}_{2}$. The formula of the dry pozzolana cements employed in this test had slag/Class F fly ash ratios of 100/0, 80/20, $60 / 40,40 / 60$, and 20/80 by weight. Sodium silicate powder served as alkali activator, and its $4 \%$ by the total weight of pozzolana cement was added to prepare the dry mix cementitious reactant. For comparison purpose, the commercial Class G well cement was used as control.

Sodium carboxymethyl cellulose (CMC) was produced by etherification of cellulose from renewable resources, like wood. CMC under the production name "Walocel CRT 30 PA," supplied by Dow Chemical Corp., was used as the thermal degradable additive to promote the disintegration of the slag/Class F fly ash-based sealers; it dissolves in water, forming an anionic polymer. Our previous work on slag/Class C fly ash system 
demonstrated that an effective amount of CMC in promising self degradation was $\geq 0.7$

$\%$ by total weight of dry slag/Class $\mathrm{C}$ fly ash/sodium silicate activator mixture. Thus, we again used its $0.7 \%$ in the current experiment.

The alkali-activated slag/Class F fly ash (AASF) slurries with CMC were prepared by adding an appropriate amount of water to the dry mix cementitius component, and then left them in an atmospheric environment until the cement set. Afterward, the room temperature-set AASF samples were exposed in an autoclave at $200^{\circ} \mathrm{C}$ for 5 hours; some autoclaved samples then were heated for 24 hours in over at $200^{\circ}, 250^{\circ}$, and $300^{\circ} \mathrm{C}$. The commercial Class $\mathrm{G}$ well cement without $\mathrm{CMC}$ also was exposed to the same conditions as that of AASF samples.

\section{Measurements}

The initial- and final-setting times of CMC-containing AASF sealing slurries at $85^{\circ} \mathrm{C}$ were determined in accordance with modified ASTM C 191-92. In it, a slurry-filled conical mold was placed in screw-topped round glass jar to avoid any evaporation of water from slurry during heating. The slurry was examined every 30 minutes to determine its setting time. The porosity of autoclaved and heated CMC-containing AASF was measured by helium pyconometry. The specimens with size, $35 \mathrm{~mm}$ diameter $\mathrm{x} 70$ $\mathrm{mm}$ length were used for porosity and compressive strength testing. X-ray powder diffraction (XRD) and Fourier transform infrared spectroscopy (FT-IR) were used to identify the crystalline and amorphous hydrothermal reaction products of the autoclaved samples. The high-resolution scanning electron microscopy (HR-SEM) was employed to survey any alternations in the microstructure of sealers before and after its selfdegradation, and also to explore the morphologies of the crystalline and amorphous hydrothermal reaction products formed in sealers. To identify these reaction products, we used energy-dispersible x-ray (EDX) concomitant with HR-SEM.

With a Type $\mathrm{K}$ thermometer, in conjunction with temperature data logger, we monitored the heat energy generated in a self-degrading process of the $200^{\circ}-, 250^{\circ}$-, and $300^{\circ} \mathrm{C}$ heated AASF specimens after their contact with water. 


\section{Results and Discussion}

\section{Properties of Slag/Class F fly ash System}

Our first experiment was directed towards gaining data on the setting time and compressive strength of CMC-containing AASF samples made with slag (S)/Class F fly ash $(\mathrm{F})$ ratios of 100/0, 80/20, 60/40, 40/60, and 20/80. Table 2 shows the changes in water content, expressed as the ratio of water (w) to dry cement (c), as a function of the $\mathrm{S} / \mathrm{F}$ ratio used in preparing the AASF slurries; it includes their initial- and final-setting times at $85^{\circ} \mathrm{C}$. The water content in these AASF systems was adjusted to attain a consistency similar to that of Class $G$ well cement slurries made with the w/c ratio of 0.39. As is evident, the w/c ratio decreased with the replacement of some portion of slag by Class F fly ash. The $0.47 \mathrm{w} / \mathrm{c}$ ratio of slurry made with 100/0 S/F ratio (no Class F fly ash) declined by $15 \%$ to 0.40 when more than $60 \mathrm{wt} \%$ of slag was replaced by Class $\mathrm{F}$ fly ash. For commercial Class G well cement, no initial set was apparent after exposure for $60 \mathrm{~min}$ in an oven at $85^{\circ} \mathrm{C}$, but extending the exposure time to $90 \mathrm{~min}$ resulted in its final set, demonstrating that both its initial- and final-setting took place within $30 \mathrm{~min}$. In contrast, all AASFs had at least 30-min span between the initial and final settings. The elapsed time for AASF's initial setting depended directly on the S/F ratios; with 100/0 $\mathrm{S} / \mathrm{F}$ ratio, it was $\sim 30$ minutes, corresponding to a 60 min shorter than that of the Class $\mathrm{G}$ slurries. Replacing $20 \%$ of the slag with fly ash delayed this initial setting time to $\sim 60$ minutes. A further delay was observed in the slurries made with the incorporation of more Class F fly ash into slag. For instant, those slurries with a 60/40 and 40/60 S/F ratio had an initial setting time of $\sim 150$ minutes and $>210$ minutes, respectively. Furthermore, the span between the initial and final setting times was related to the initial setting time; namely, the slurries with a slower initial setting had a longer time span. In fact, this span of 100/0 ratio with a fast initial setting of $\sim 30$ minutes was only 30 minutes. Compared with this, a longer span of $\sim 60$ and $\sim 120$ min was observed from the 80/20 and 60/40 ratios along with $\sim 60$ and $\sim 150$ min initial setting time, respectively. Thus, a predominance of slag in the mix seemingly accelerated both the initial- and final- setting of slurries. 
Figure 1 compares the compressive strength of the specimens made with 100/0,80/20, $60 / 40,40 / 60$, and $20 / 80 \mathrm{~S} / \mathrm{F}$ ratios after exposure to four different thermal conditions, as described in Experimental Procedure. For comparison, Class G well cement was tested under the same conditions. As is seen, two major factors governed the changes in compressive strength for AASF systems: One factor was the S/F ratio; the other was the subsequent temperature of heat exposure of the autoclaved specimens. For all the specimens, excepting the $20 / 80$ ratio one, autoclaving them at $200^{\circ} \mathrm{C}$ was responsible for developing a higher compressive strength, rather than that the temperature to which they subsequently were exposed to heat. The compressive strength of all autoclaved specimens, excepting 20/80 ratio, were more than three-fold greater than that of autoclaved Class $\mathrm{G}$ well cement. As described in our previous report, $\mathrm{CMC}$ additive as a self degradation promoter in the sealer did not decompose hydrothermally in the autoclave, but it was decomposed during the exposure in an over at temperatures of $\geq 200^{\circ} \mathrm{C}$. Its decomposition therein led to the emission of several different gaseous species such as $\mathrm{CO}_{2}, \mathrm{CO}, \mathrm{CH}_{4}$, and $\mathrm{CH}_{3} \mathrm{COOH}$, which created a porous cementitious structure encompassing copious cavities and pores. This emission process was a major reason why the compressive strength of all the heated specimens was lower than that of autoclaved ones. Upon autoclaving, the extent of strength's development depended on the S/F ratios; the specimens made with this higher ratio displayed greater strength than those with lower $\mathrm{S} / \mathrm{F}$ ratios. In fact, the specimens with the 100/0 ratio had the highest compressive strength of 6691 psi, corresponding to improvement of $\sim 11, \sim 21, \sim 28$, and $\sim 88 \%$ over those with a ratio of $80 / 20,60 / 40,40 / 60$, and $20 / 80$.

On heating of autoclaved specimens at temperatures from $200^{\circ} \mathrm{C}$ to $300^{\circ} \mathrm{C}$, the compressive strength for all specimens, except for 20/80 ratio and Class G well cement, tended to decline with rising temperature. With a 100/0 ratio, the compressive strength of $200^{\circ} \mathrm{C}$-autoclaved specimens fell $\sim 28 \%$ to $4789 \mathrm{psi}$, when they were heated at $200^{\circ} \mathrm{C}$. A further increasing temperature to $250^{\circ} \mathrm{C}$ caused its reduction of $\sim 39 \%$, while a 3683 psi compressive strength at $300^{\circ} \mathrm{C}$ corresponded to $\sim 45 \%$ reduction from the original value of the autoclaved specimen. A similar tendency to decrease the compressive strength with increasing temperature was observed in the autoclaved 80/20,60/40, and 40/60 ratio 
specimens. In contrast, no significant changes in compressive strength were observed in 20/80 ratio and Class G well cement specimens. As described in our previous report [1], the major thermal decomposition curve of CMC by Differential scanning calorimetry (DSC) revealed the beginning of decomposition at $165^{\circ} \mathrm{C}$, the endothermic decomposition peak at $270^{\circ} \mathrm{C}$, and its end at $295^{\circ} \mathrm{C}$. Since the temperature at the endothermic peak represented the highest rate of thermal decomposition, a rise in the heating temperature from $200^{\circ} \mathrm{C}$ to $300^{\circ} \mathrm{C}$ enhanced the emission of gaseous species generated by the thermal decomposition of CMC. In the other words, rising temperature promoted the rate of $\mathrm{CMC}$ solid $\rightarrow$ gas phase transformation, reflecting directly the development of porous structure in sealer.

Nonetheless, the development of in-situ porous cementitious structure along with a retrogressed compressive strength at heating temperatures $\geq 200^{\circ} \mathrm{C}$ was a very important aspect in subserving the disintegration of sealers through the self-degradation pathway described in the introduction section.

To verify this porosity-temperature relation, we determined the porosity of AASF and Class $\mathrm{G}$ cement after exposing them to different heat temperatures (Figure 2). After drying the autoclaved AASF specimens for 24 hours at $85^{\circ} \mathrm{C}$, the porosity of the $100 / 0$, $80 / 20,60 / 40$, and $40 / 60$ ratios ranged from 8.9 to $11.5 \%$, while the $20 / 80$ ratio had a much higher porosity of $45.6 \%$. The autoclaved Class $\mathrm{G}$ cement had a porosity of 35.5 $\%$. When these autoclaved specimens were heated in an oven at temperatures from $200^{\circ} \mathrm{C}$ to $300^{\circ} \mathrm{C}$, the porosity of all AASF specimens, except for $20 / 80$ ratio, markedly increased with a rising heat temperature. Furthermore, the rate of increase in porosity was associated with S/F ratio. With a 100/0 ratio, the porosity of the autoclaved specimens rose 1.7-, 2.3-, and 3.1-fold to $14.9,20.6$, and $27.6 \%$, respectively, at $200^{\circ}, 250^{\circ}$, and $300^{\circ} \mathrm{C}$. Compared with this, the specimens with a lower ratio of $40 / 60$ resulted in the incorporation of even more pores and voids into sealer, reflecting a 2.2-, 3.2-, and 3.9fold increase at $200^{\circ}, 250^{\circ}$, and $300^{\circ} \mathrm{C}$. As is evident, at $300^{\circ} \mathrm{C}$, the efficiency of $\mathrm{CMC}$ in creating a porous structure in the sealer was better than that at $200^{\circ}$ and $250^{\circ} \mathrm{C}$. In addition, the sealers made with lower $\mathrm{S} / \mathrm{F}$ ratios favorably incorporated more voids and 
pores into their bodies, compared with those having a higher ratio. In contrast, neither the Class $\mathrm{G}$ well cement nor specimens with a 20/80 ratio displayed any significant changes in porosity as a function of temperature, suggesting that increased temperatures were not as effective in incorporating additional pores and voids in them as in the other AASF specimens.

Thus, the information described above clearly verified that exposure to higher temperature assured a better performance of $\mathrm{CMC}$ in creating porous structure of sealers than that to lower temperature.

\section{XRD and FT-IR Analyses}

To obtain information on what kind of hydrothermal reaction products contributed to the development of strength in the AASF sealers, our attention now was paid to identifying the crystalline and amorphous reaction products formed in the $200^{\circ} \mathrm{C}$-autoclaved specimens with various different $\mathrm{S} / \mathrm{F}$ ratios.

Figure 3 depicts the XRD tracings, ranging from 5 to $51(2 \theta$, degree), for autoclaved AASF specimens, and also it includes "as-received" slag and Class F fly ash as the starting materials. For slag, XRD pattern (a) revealed the typical amorphous feature of $\mathrm{CaO}-\mathrm{Al}_{2} \mathrm{O}_{3}-\mathrm{MgO}-\mathrm{SiO}_{2}$ glass structure. The pattern (b) for Class $\mathrm{F}$ fly ash consisted of three crystalline phases, quartz $\left(\mathrm{SiO}_{2}\right)$, mullite $\left(3 \mathrm{Al}_{2} \mathrm{O}_{3} \cdot 2 \mathrm{SiO}_{2}\right)$, and hamatite $\left(\mathrm{Fe}_{2} \mathrm{O}_{3}\right)$. The specimen made with 100/0 ratio (c) without Class F fly ash formed only single crystalline phase associated with the calcium silicate hydrate (I) $\left[\mathrm{CaO} \cdot \mathrm{SiO}_{2} \cdot \mathrm{H}_{2} \mathrm{O}, \mathrm{C}-\mathrm{S}-\mathrm{H}\right.$ (I)] as the $200^{\circ} \mathrm{C}$ hydrothermal-catalyzed pozzolanic reaction product, suggesting that the hydrothermal reaction between slag and sodium silicate activator led to the formation of C-S-H (I) phase responsible for strengthening 100/0 ratio specimen as illustrated below:

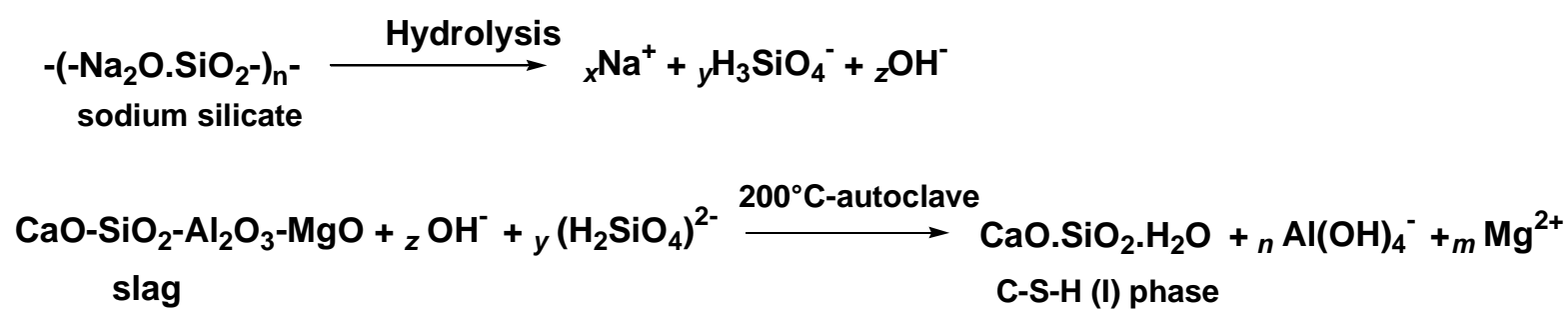


In this reaction, the hydrolysis of sodium silicate activator in water generated two major reactants, ionized monosilicic acid $\left(\mathrm{H}_{3} \mathrm{SiO}_{4}{ }^{-}\right)$and hydroxyl anion $\left(\mathrm{OH}^{-}\right)$, and then these ionic species reacted with slag to form C-S-H (I) phase. Replacing $20 \%$ of the slag with Class F fly ash, XRD pattern (d) with 80/20 ratio was characterized by forming the 1.1 nm tobermorite $\left[\mathrm{Ca}_{5}(\mathrm{OH})_{2} \mathrm{Si}_{6} \mathrm{O}_{16} .5 \mathrm{H}_{2} \mathrm{O}\right]$ phase, rather than C-S-H, while some nonreacted Class F fly ashes remained in an autoclaved cementitious bodies. The similar XRD pattern, except for the presence of more intensive $d$-spacing lines relative to the remaining Class F fly ash, was observed from 60/40 ratio (e). Figure 4 shows the HRSEM images coupled to EDX-derived atomic compositions of both the Class F fly ash remnant and tobermorite reaction products in the 60/40 ratio specimen. For the former, the image revealed its typical micro-size spherical feature comprising three major elements, oxygen, aluminum, and silicon, some of which were assignable to mullite and quartz. The well-formed tobermorite was identified by the interlocking conformation of thin plate-like crystals. EDX atomic composition of these crystal consisted of $19.2 \%$ oxygen, $18.9 \%$ aluminum, $29.0 \%$ silicon, $31.6 \%$ calcium, and $1.3 \%$ iron. Among those, three elements, oxygen, silicon, and calcium, belonged to the formation of tobermorite. As well documented [6-8], aluminum element can be intercalated into the structure of $1.1 \mathrm{~nm}$ tobermorite during hydrothermal curing condition around $180^{\circ} \mathrm{C}$. Thus, the presence of aluminum in this crystal demonstrated that this crystal formed hydrothermally at $200^{\circ} \mathrm{C}$ was the aluminum-substituted $1.1 \mathrm{~nm}$ tobermorite, $\mathrm{Ca}_{5} \mathrm{AlSi}_{5} \mathrm{O}_{16} .5 \mathrm{H}_{2} \mathrm{O}$. Thus, we believed that the aluminum liberated during interactions between sodium silicate activator and Class F fly ash or slag/or both acted to form the aluminum-substituted tobermorite crystal with a high molecular weight (MW) of 713.67, compared to C-S-H (I) with a low MW of 134.14.

In contrast, a striking decay and disappearance of all tobermorite-related $d$-spacing lines was observed from 40/60 S/F (f) and 20/80 S/F (g), while most of $d$-spacings in their XRD patterns belonged to non-reacted Class F fly ash. Hence, it is possible to rationalize that the strength developed in specimens made with Class F fly ash-predominated formulas perhaps reflected not only poorly formed tobermorite, but also a possible 
contribution from an amorphous reaction product yielded by the hydrothermal interactions between sodium silicate activator and Class F fly ash.

To identify this amorphous reaction product, we analyzed $40 / 60$ and 20/80 ratio specimens using FT-IR. The "as-received" Class F fly ash and sodium silicate activator were used as references. All specimens were dried in an oven at $85^{\circ} \mathrm{C}$ for 24 hours before analyzing them. Figure 5 illustrates the resulting FT-IR spectra, ranging from 1800 to 500 $\mathrm{cm}^{-1}$, of both the specimens and references. For the references, a typical spectrum (a) of sodium silicate had the following absorption bands: According to literatures [9-12], at $1635 \mathrm{~cm}^{-1}$ due to adsorbed $\mathrm{H}_{2} \mathrm{O}$; at 1452 and $711 \mathrm{~cm}^{-1}$ associated with $\mathrm{CO}_{3}{ }^{2-}$ in carbonates, at $1029 \mathrm{~cm}^{-1}$ ascribed to the oxygen-bridging Si-O-Si asymmetric stretching, at $970 \mathrm{~cm}^{-1}$ reflecting non oxygen-bridging Si-O ${ }^{-}$stretching in $\mathrm{Na}^{+}{ }^{-} \mathrm{O}-\mathrm{Si}$ - linkage, at 882 $\mathrm{cm}^{-1}$ assigned to the Si-OH bending, and at $592 \mathrm{~cm}^{-1}$ attributed to the O-Si-O bending. The spectrum of Class F fly ash (b) revealed the presence of four major groups; carbonate-related $\mathrm{CO}_{3}{ }^{2-}$ at 1419 and $693 \mathrm{~cm}^{-1}$, silica-associated Si-O in-plane vibration at $1085 \mathrm{~cm}^{-1}$, silicate-related Si-O-Si linkage at $1029 \mathrm{~cm}^{-1}$, and tetrahedral aluminum-related Si-O-Al linkage at $795 \mathrm{~cm}^{-1}$. Compared with that of Class F fly ash, the $40 / 60 \mathrm{~S} / \mathrm{F}$ ratio specimen exhibited three distinctive features (c): First, it developed a strong band at 1452 $\mathrm{cm}^{-1}$ attributed to the carbonates; second, a shoulder band at $1029 \mathrm{~cm}^{-1}$ corresponding to Si-O-Si linkage in silicate became a pronounced band; thirdly, a strong new band at 970 $\mathrm{cm}^{-1}$ due to the $\mathrm{Na}^{+}{ }^{-} \mathrm{O}-\mathrm{Si}$ - linkage was emerged. Most of sodium silicate activator as the starting material had dissolved in the cementitious slurry; in fact, the sharp O-Si-O band at $592 \mathrm{~cm}^{-1}$ representing sodium silicate, did not see in this spectrum. As a result, seemingly, the amorphous reaction product is likely to be the polymeric zeolite in terms of geopolymer. As described in our previous paper [13], the geopolymer was assembled through the three step-reaction pathways, alkali dissociation $\rightarrow$ interaction $\rightarrow$ selfpolycondensation (Figure 6). The first step of this pathway was the dissociation of mullite in the Class F fly ash in the alkali medium derived from the hydrolysis of sodium silicate activator, yielding two ionic reactants, $\mathrm{Al}(\mathrm{OH})_{4}{ }^{-}$and $\mathrm{H}_{3} \mathrm{SiO}_{4}{ }^{-}$. The second step was the interactions between these two anionic reactants and $\mathrm{Na}$ cation as a counter ion from sodium silicate to form pre-geopolymer, and then the final step in assembling the 
geopolymer was the self-polycondensation reactions between pre-geopolymers. Thus, the amorphous geopolymer was responsible for the development of the compressive strength of the $40 / 60$ ratio specimen.

To visualize the morphology of amorphous geopolymer as cementitious binder, we explored the fracture surface of autoclaved 40/60 ratio specimen using HR-SEM coupled with EDX (Figure 7). The HR-SEM image revealed the cluster of fine fibrous-like reaction products growing on the surfaces of Class F fly ash spheres, wherein, the cohesively agglomerated masses of these cluster acted as cementitious structure. The EDX atomic composition of this reaction product distinguished four major elements, oxygen, sodium, aluminum, and silicon, attributed to geopolymer, along with three minor elements, potassium, calcium, and iron. The geopolymer reaction products formed on the surfaces of fly ash spheres, accounting for the interaction between sodium silicate and fly ash. The image also revealed that this agglomerated microstructure contained numerous voids, denoting that the geopolymer-based cementitious structure was poorly formed in the 40/60 ratio specimen; and the incorporation of additional sodium silicate was needed to create a well-formed geopolymer and to densify the geopolymer's structure. Overall, the phase composition assembled in the 40/60 ratio specimen was comprised of amorphous geopolymer as the major reaction product and crystalline aluminumsubstituted $1.1 \mathrm{~nm}$ tobermorite as the minor one.

The XRD spectral feature of the 20/80 ratio (d) closely resembled to that of the 40/60 one, suggesting that the combination of geopolymer as the major phase and aluminumsubstituted $1.1 \mathrm{~nm}$ tobermorite as the minor one conferred the development of strength on the $20 / 80$ ratio specimen. Compared with the microstructure of the $40 / 60$ ratio, the microstructure of the 20/80 ratio was more porous, rich in voids. This was caused by two undesirable factors: One factor was a very poor formation of geopolymer-based cementitious structure including a copious number of pores; the other was related to a large number of non-reacted Class F fly ash remnants. Although there was no presence of FT-IR spectrum in any figures, the formation of geopolymer as the minor reaction product was detected in the $60 / 40$ ratio, but not in the $80 / 20$ ratio. 
Table 3 summarizes the compressive strength, porosity, and hydrothermal reaction product for $100 / 0,80 / 20,60 / 40,40 / 60$, and 20/80 ratio specimens after autoclaving at $200^{\circ} \mathrm{C}$. As is evident from table, the ranking of reaction products contributing to the higher compressive strength and lower porosity was in the following order; crystalline C$\mathrm{S}-\mathrm{H}(\mathrm{I})>$ crystalline aluminum-substituted $1.1 \mathrm{~nm}$ tobermorite $>$ amorphous geopolymer. Correspondingly, the poorly formed geopolymer-based cementitious structure in the $20 / 80$ ratio had the highest porosity of $45.6 \%$, corresponding to the lowest compressive strength. Additionally, the development of such porous structure was due not only to the formation of void-rich geopolymer, but also reflected the presence of abundant nonreacted Class F fly ash remnants.

Although the C-S-H (I)-associated 100/0 ratio specimen displayed outstanding compressive strength and a denser structure, its one shortcoming was its rapid initial setting of $\sim 30 \mathrm{~min}$ at $85^{\circ} \mathrm{C}$ that failed to meet the criterion $\geq 60 \mathrm{~min}$. Thus, no further test was conducted for $100 / 0$ ratio.

\section{Self-degradation}

Our focus next centered on visualizing the self-degradation of AASF sealers made with $80 / 20,60 / 40,40 / 60$, and $20 / 80 \mathrm{~S} / \mathrm{F}$ ratio. To do so, we adapted the same experimental method as that of our previous work on the slag/Class C fly ash system. The detailed test procedures were as follows; 1) the specimens were autoclaved at $200^{\circ} \mathrm{C}$ for 5 hours, and then heated at $200^{\circ}, 250^{\circ}$, and $300^{\circ} \mathrm{C}$ for 24 hours, 2) the specimens were cooled for 24 hours at room temperature, 3 ) thermocouple-embedded specimens were placed in a vacuum chamber at $-1000 \mathrm{kPa}$ for $10 \mathrm{~min}$ to eliminate any air present in the specimens, 4) air-free voids in the vacuumed specimens were filled with water (water/specimens

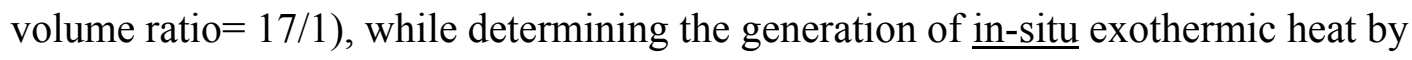
temperature data logger, and 5) visual observation was made to evaluate the magnitude of self-degradation. 
Figure 8 plots the in-situ exothermic temperature generated in the vacuumed AASF specimens as a function of elapsed time after they were impregnated with water. For $80 / 20$ ratio, the resulting temperature-time relation cure showed that $\sim 120 \mathrm{sec}$ after impregnating the specimen with water, its internal temperature rapidly rose from $16^{\circ} \mathrm{C}$ to a peak of $40^{\circ} \mathrm{C}$. The total elapse time from the onset to the maximum temperature was only $238 \mathrm{sec}$. We observed the development of numerous cracks in the waterimpregnated specimens along with the increase in their exothermic temperature. Hence, the penetration of water through the specimen led to the evolution of in-situ exothermic heat promoting the self-degradation of the sealer. Although the similar feature of curve was recorded in the $60 / 40$ ratio specimen, its peak temperature was $9^{\circ} \mathrm{C}$ lower than that of 80/20 ratio, suggesting that more displacement of slag portion by Class F fly ash engendered the reduction of in-situ exothermic heat evolved in the water-impregnated specimen. We also observed that this $60 / 40$ ratio specimen was degraded by water penetration (Figure 9). Figure 10 compares the HR-SEM image of the fractured surfaces for the $200^{\circ} \mathrm{C}$-heated $60 / 40$ ratio specimen before and after its self-degradation. Before a self-degradation, the image showed a dense, relatively smooth surface texture as a typical hard cementitious structure containing some non-reaction Class F fly ash spheres. Compared with this, a dramatic alteration in microstructure was observed from the fractured surface of self-degraded specimen. The image expressed that the ordinal cementitious structure converted into a very rough, porous structure during a selfdegrading process, strongly demonstrating that the evaluation of in-situ exothermic heat acted to promote an internal disintegration of the cementitious structure.

In contrast, there was no generation of the exothermic peak for 40/60 and 20/80 ratios. Their curves revealed a slight increase in temperature after $\sim 130 \mathrm{sec}$ from the beginning of water impregnation, but beyond this time, they leveled off. Furthermore, these specimens did not show any signs of the self-degradation and - breakage, and nor were visual cracks and fissures observed in the specimens.

Based upon out previous study [1], Figure 11 delineated the self-degradation mechanism for alkali-activated cementitious material (AACM). In this mechanism, there were two 
important factors: One factor was the presence of free sodium hydroxide as reactant derived from the hydrolysis of sodium silicate activator in the AACM slurries; the other was related to the formation of ionic carbonic acid from wet carbonation of $\mathrm{CO}_{2}$ emitted from thermal degradation of CMC. The sodium hydroxide directly reacted with ionic carbonic acid to form sodium bicarbonate. Then, the chemical affinity of sodium bicarbonate with $\mathrm{CH}_{3} \mathrm{COOH}$ from the decomposed $\mathrm{CMC}$ led to the evolution of $\mathrm{CO}_{2}$ as reaction product. In-situ exothermic energy was generated throughout this process, including dissolution, interactions, and evolution. Nevertheless, we considered that this in-situ $\mathrm{CO}_{2}$ gas evolution and sodium acetate as exothermic reaction product led to volume expansion of AACM, thereby resulting in the breakage and disintegration of AACM.

As is evident from this mechanism, the sodium hydroxide hydrolysate played a pivotal role in promoting the self-degradation of sealers. In the 40/60 and 20/80 ratio specimens comprising of geopolymer as the major reaction product, the amount of free sodium hydroxide dissociated in the water-impregnated specimens may be very little, if any, because the polymeric network structure of geopolymer was constituted of sodium aluminum silicate compounds. Thus, it is reasonable to assume that the intercalation of sodium in its polymeric networks impaired the production of sodium hydroxide, thereby declining the evolution of in-situ exothermic heat promoting the self-degradation. Correspondingly, the 20/80 ratio attributing to more consumption of sodium hydroxide to form geopolymer had the lowest heat evolution. The lack of free sodium hydroxide was the major reason why these geopolymer-based $40 / 60$ and 20/80 ratio specimens remained intact in terms of non-self degradation. Thus, although the geopolymer-based sealers had a porous structure, its structure did not help in promoting the sealer's self-degradation. As a result, the magnitude of self-degradation was directed toward the exothermic temperature generated in the water-impregnated sealers; a higher exothermic temperature conferred adequate breakages on the sealer.

Returning to the self-degradation mechanism, the other important factor governing the self-degradation was the amount of $\mathrm{CO}_{2}$ and $\mathrm{CH}_{3} \mathrm{COOH}$ as the gaseous by-products 
emitted by the thermal decomposition of CMC. A large volume of these emitted byproducts in an aqueous medium would generate more exothermic heat by the interactions between the carbonate or sodium hydroxide and $\mathrm{CH}_{3} \mathrm{COOH}$. Thus, our focus next was shifted to investigating the effectiveness of the thermal decomposition temperature of $\mathrm{CMC}$ in rising this exothermic temperature. Figure 12 illustrates the exothermic temperature-elapsed time relation for $80 / 20$ ratio specimens after heating at $200^{\circ}, 250^{\circ}$, and $300^{\circ} \mathrm{C}$. The data revealed the rise in peak exothermic temperature with an increasing heat treatment temperature; in fact, the peak at $40^{\circ} \mathrm{C}$ evolved in the $200^{\circ} \mathrm{C}$-heated specimen shifted in a high temperature site to $42^{\circ} \mathrm{C}$, when it was heated at $250^{\circ} \mathrm{C}$. Further shift to a higher temperature of $44^{\circ} \mathrm{C}$ was recorded from the $300^{\circ} \mathrm{C}$-heated specimen. It appeared from this result that the extent of exothermic heat evolution depended on the thermal decomposition temperature of CMC. In the other words, the heat treatment at $300^{\circ} \mathrm{C}$ provided a better efficacy in enhancing the magnitude of self-degradation than that at lower temperatures of $250^{\circ}$ and $200^{\circ} \mathrm{C}$.

With the 60/40 ratio, the exothermic temperature-elapsed time curve (Figure 13) exhibited the similar trend to that of $80 / 20$ ratio; the peak exothermic temperature increased with an increasing heat treatment temperature. However, at $300^{\circ} \mathrm{C}$, its highest peak temperature of $41.5^{\circ} \mathrm{C}$ was $2.5^{\circ} \mathrm{C}$ lower than that of $80 / 20$ ratio treated with the same temperature, suggesting that the formation of some geopolymer in the $60 / 40$ ratio caused the reduction of exothermic heat evolution.

\section{Conclusion}

We evaluated in the laboratory a potential of alkali-activated slag/Class F (AASF) cementitious system as an alternative self-degradable temporary sealing material. The formulated AASF system included the five different slag/Class F fly ash (S/F) ratios, $100 / 0,80 / 20,60 / 40,40 / 60$, and 20/80. These formulas were modified with two additives: One was sodium silicate as powdered alkali activator at $4 \%$ of the total weight of dry slag/Class F fly ash mixture; the other was sodium carboxymethyl cellulose (CMC) powder as the self-degradation promoter at $0.7 \%$ of the total weight of dry slag/Class $\mathrm{F}$ fly ash/alkali activator blend. The three major material criteria for screening the candidate 
temporary sealers were set: 1) An initial setting time of $\geq 60$ min at $85^{\circ} \mathrm{C}, 2$ ) compressive strength $\geq 2000 \mathrm{psi}$ after autoclaving at $200^{\circ} \mathrm{C}$ and heating at $200^{\circ}, 250^{\circ}$, and $300^{\circ} \mathrm{C}$, and 3) self-degrading capability when sealers hearted at $\geq 200^{\circ} \mathrm{C}$ came in contact with water.

The initial setting time at $85^{\circ} \mathrm{C}$ depended on the $\mathrm{S} / \mathrm{F}$ ratios; a decrease in this ratio extended setting time from $\sim 30 \mathrm{~min}$ for $100 / 0$ ratio to $>210 \mathrm{~min}$ for $20 / 80$ one. The phase identification study for $200^{\circ} \mathrm{C}$-autoclaved AASF specimens revealed that the crystalline calcium silicate hydrate (I) [C-S-H (I)] as a hydrothermal reaction product was formed in $100 / 0$ ratio specimen. Further, this reaction product contributed to the development of the highest compressive strength of 6691 psi in this test series. No C-S-H (I) phase was identified in any other $\mathrm{S} / \mathrm{F}$ ratios. The aluminum-substituted $1.1 \mathrm{~nm}$ tobermorite phase consisting of thin plate-like crystal was responsible for strengthening the specimens made with $80 / 20$ and $60 / 40$ ratios, reflecting the compressive strength of 5983 psi to 5271 psi, respectively. The latter ratio also encompassed a geopolymer phase as an amorphous hydrothermal reaction product. Although $1.1 \mathrm{~nm}$ tobermorite was present as the minor phase in the 40/60 and 20/80 ratios, amorphous geopolymer played the essential role in developing their respective compressive strength of 4790 psi and 789 psi. However, the geopolymer-based cementitious microstructure assembled in these ratio specimens was porous, and hence undesirable. The incorporation of addition sodium silicate into these ratios would be required to create a well-formed geopolymer and to densify its structure. All autoclaved AASF specimens, except for 20/80 ratio, exhibited a decline in compressive strength after heating $\geq 200^{\circ} \mathrm{C}$; in fact, at $300^{\circ} \mathrm{C}$, the strength of $100 / 0$, $80 / 20,60 / 40$, and $40 / 60$ ratios fell $\sim 45, \sim 46, \sim 46$, and $\sim 57 \%$, compared with that of autoclaved specimens. This decline in strength was correlated directory with an increasing porosity in AASF bodies; at $300^{\circ} \mathrm{C}$, the porosity of autoclaved $100 / 0,80 / 20$, $60 / 40$, and 40/60 ratios, ranging from $8.9 \%$ to $10.1 \%$, had increased, respectively, by 3.1-, 3.6-, 4.3-, and 3.9-fold. On heating at $\geq 200^{\circ} \mathrm{C}$, the porous structure that developed in the autoclaved specimens reflected the emission of $\mathrm{CO}_{2}, \mathrm{CO}, \mathrm{CH}_{4}$, and $\mathrm{CH}_{3} \mathrm{COOH}$ as gaseous by-products from the thermal decomposition of CMC. This emission was enhanced with an increasing heat temperature, and accordingly, AASF specimens exposed to higher temperatures had a more porous structure. 
The 100/0 ratio failed to meet the criterion of initial setting time because it set quickly in $\sim 30 \mathrm{~min}$ at $85^{\circ} \mathrm{C}$. Thus, we did not explore its self-degradation. There were two factors governing the magnitude of self-degradation of AASF sealers heated at $\geq 200^{\circ} \mathrm{C}$, followed by water impregnation: One factor was the hydrothermal reaction products responding to the mechanical strength of sealers; the other was related to the thermal decomposition temperature of CMC. In the first factor, aluminum-substituted $1.1 \mathrm{~nm}$ tobermorite phase formed in the $80 / 20$ and $60 / 40$ ratio specimens allowed the sealer to disintegrate readily. In contrast, the geopolymer phase formed in 40/60 and 20/80 ratio specimens prevented the self-degradation of sealers, and they remained intact. Since the self-degradation of sealer primary was due to the in-situ exothermic heat evolved by the interactions between sodium hydroxide hydrolysate from sodium silicate, and $\mathrm{CO}_{2}$ and $\mathrm{CH}_{3} \mathrm{COOH}$ emitted by thermal decomposition of CMC in an aqueous medium, it was very important for free sodium hydroxide to be present in the sealer. However, the polymeric network structure of geopolymer was assembled in the reactions between sodium hydroxide and mullite in Class F fly ash. This was the major reason why the geopolymer-based sealer did not disintegrate because the free sodium hydroxide had been consumed in assembling the geopolymer structure.

Regarding the second factor, the increase in heat temperature generated more emission of gaseous by-products from CMC, corresponding to an enhanced generation of in-situ exothermic heat contributing to self-degradation. In fact, $300^{\circ} \mathrm{C}$ - and $250^{\circ} \mathrm{C}$-heated $80 / 20$ and 60/40 ratio sealers exhibited a higher exothermic temperature, compared with that of $200^{\circ} \mathrm{C}$-heated same sealers. Based upon the visual observation, the sealers generating a higher exothermic temperature underwent sever disintegration due to the development and propagation of wide cracks and fissures. Therefore, we recommend the 80/20 and $60 / 40$ ratio formulas as alternative self-degradable temporary sealers.

For comparison with the characterization of self-degradable slag/Class C fly ash systems developed previously at BNL, Table 4 lists the properties of 20/80 slag/Class C fly ash ratio-, and 80/20 and 60/40 slag/Class F fly ash ratio-based cementitious materials that 
have high potential as temporary fracture sealers. These properties involved their initial setting time at $85^{\circ} \mathrm{C}$, compressive strength, porosity, phase composition as hydrothermal reaction product, and the exothermic temperature evolved in $200^{\circ} \mathrm{C}$ - and $250^{\circ} \mathrm{C}$ - heated sealers before and after autoclaving at $200^{\circ} \mathrm{C}$. Nevertheless, we selected these three formulas for a further R\&D work on the development of the expansible temporary sealers to improve their adherence to fractured inner-rock surfaces.

\section{References}

1. T. Sugama, T. Butcher, L. Brothers, and D. Bour "Self-degradable cementitious sealing materials," BNL-94308-2010-IR, October 2010.

2. S. Anand, P. Vrat, and R.P. Dahiya "Application of a system dynamics approach for assessment and mitigation of $\mathrm{CO}_{2}$ emission from the cement industry," $\mathrm{J}$. Environmental Management, 79 (2006) 383-398.

3. T. L. Mlakar, M. Horvat, T. Vuk, A. Stergarsek, J. Kotnik, J. Tratnik, and V. Fajon "Mercury species, mass flows and processes in a cement plant," Fuel, 89 (2010) 1936-1945.

4. R.S. Kalyoncu "Slag-iron and steel," U.S. Geological Survey Minerals Yearbook, 2000. http://minerals.usgs.gov/minerals/pubs/commodity/iron_\& steel_slag/790400.pdf.

5. T.D. Kelly, D.E. Sullivan, and H. van Oss "Coal combustion products statistics," U.S. Geological Survey, Last modification: December 1, 2010. http://minerals.usgs.gov/ds/2005/140/coalcombustionproducts.pdf.

6. L. Black, A. Stumm, K. Garbev, P. Stemmermann, K.R. Hallam, and G.C. Allen "X-ray photoelectron spectroscopy of aluminum-substituted tobermorite," Cem. Concr. Res. 35 (2005) 51-55.

7. P. Faucon, J.C. Petit, T. Charpentier, J.F. Jacquinot, F. Adenot "Silicon substitution for aluminum in calcium silicate hydrates," J. Am. Ceram. Soc. 82 (1999) 1307-1321.

8. M. Mituda and H.F.W. Taylor "Influence of aluminum on the conversion of calcium silicate hydrate gels into $1.1 \mathrm{~nm}$ tobermorite at $90^{\circ}$ and $120^{\circ} \mathrm{C}$," Cem. Concr. Res. 5 (1975) 203-210. 
9. T. Uchino, T. Sakka, and M. Iwasaki "Interpretation of hydrated states of sodium silicate glasses by infrared and raman analysis," J. Am. Ceram. Soc. 74 (1991) 306-313.

10. B.N. Roy "Infrared spectroscopy of lead and alkaline-earth alumiosilicate glasses," J. Am. Ceram. Soc., 73 (1990) 846-855.

11. T. Uchino, T. Sakka, K. Hotta, and M. Iwasaki "Attenuated total reflectance fourier-transform infrared spectra of a hydrated sodium silicate glass," J. Am. Ceram. Soc., 72 (1989) 2173-2175.

12. V.C. Farmer and J.D. Russell "The infra-red spectra of layer silicates," Spectrochim. Acta., 20 (1964) 1149-1173.

13. T. Sugama, T. Butcher, and L. Ecker "Experience with the development of advanced materials for geothermal systems," in Materials Challenges in Alternative and Renewable Energy, [Ed.] G. Wicks, J. Simon, R. Zidan, E. LaraCurzio, T. Adams, J. Zayas, A. Karkamkar, R. Sindelar, and B. Garcia-Diaz, The American Ceramic Society, Ceramic Transactions, 224 (2011) 389-401, A John Wiley \& Sons, Inc., Publication. 
Table 1. Chemical composition of Ground Granulated Blastfurnace Slag and Class F fly ash.

\begin{tabular}{|l|l|l|l|l|l|l|l|l|l|l|}
\hline & $\begin{array}{l}\mathrm{CaO}, \\
\mathrm{wt} \%\end{array}$ & $\begin{array}{l}\mathrm{SiO}_{2}, \\
\mathrm{wt} \%\end{array}$ & $\begin{array}{l}\mathrm{Al}_{2} \mathrm{O}_{3}, \\
\mathrm{wt} \%\end{array}$ & $\begin{array}{l}\mathrm{MgO}, \\
\mathrm{wt} \%\end{array}$ & $\begin{array}{l}\mathrm{Fe}_{2} \mathrm{O}_{3}, \\
\mathrm{wt} \%\end{array}$ & $\begin{array}{l}\mathrm{TiO}_{2}, \\
\mathrm{wt} \%\end{array}$ & $\begin{array}{l}\mathrm{Na}_{2} \mathrm{O}, \\
\mathrm{wt} \%\end{array}$ & $\begin{array}{l}\mathrm{K}_{2} \mathrm{O}, \\
\mathrm{wt} \%\end{array}$ & $\begin{array}{l}\mathrm{SO}_{3}, \\
\mathrm{wt} \%\end{array}$ & $\begin{array}{l}\text { Loss in } \\
\text { ignition } \\
\text { for C, } \\
\mathrm{w} \%\end{array}$ \\
\hline Slag & 38.5 & 35.2 & 12.6 & 10.6 & 1.1 & 0.4 & - & - & 0.1 & 1.5 \\
\hline $\begin{array}{l}\text { F flass } \\
\text { ash }\end{array}$ & 0.47 & 39.3 & 38.6 & 1.4 & 12.9 & - & 1.5 & 1.9 & 1.2 & 2.7 \\
\hline
\end{tabular}

Table 2. Water/cement ratio, and initial and final setting times at $85^{\circ} \mathrm{C}$ for slurries made with various slag/Class F fly ash ratio and Class $\mathrm{G}$ well cement.

\begin{tabular}{|l|l|l|l|}
\hline & $\begin{array}{l}\text { Water/cement, } \mathrm{w} / \mathrm{c} \\
\text { ratio }\end{array}$ & $\begin{array}{l}\text { Initial setting time at } \\
85^{\circ} \mathrm{C}, \text { min }\end{array}$ & $\begin{array}{l}\text { Final setting time at } \\
85^{\circ} \mathrm{C}, \text { min }\end{array}$ \\
\hline Class G well cement & 0.39 & $\sim 90$ & $\sim 90$ \\
\hline $100 / 0 \mathrm{slag} /$ Class F & 0.47 & $\sim 30$ & $\sim 60$ \\
\hline $80 / 20 \mathrm{slag} /$ Class F & 0.45 & $\sim 60$ & $\sim 120$ \\
\hline $60 / 40 \mathrm{slag} /$ Class F & 0.42 & $\sim 150$ & $\sim 270$ \\
\hline $40 / 60 \mathrm{slag} /$ Class F & 0.40 & $>210$ & \\
\hline $20 / 80 \mathrm{slag} /$ Class F & 0.40 & $>210$ & \\
\hline
\end{tabular}

Table 3. Hydrothermal reaction products, compressive strength, and porosity for $200^{\circ} \mathrm{C}$ autoclaved specimens made with 100/0, 80/20, 60/40, 40/60, and 20/80 slag/Class F fly ash ratios

\begin{tabular}{|c|c|c|c|c|}
\hline \multirow{2}{*}{$\begin{array}{c}\text { Slag/Class F fly } \\
\text { ash, ratio }\end{array}$} & \multicolumn{2}{|l|}{ Hydrothermal reaction product } & \multirow{2}{*}{$\begin{array}{c}\text { Compressive } \\
\text { strength, psi }\end{array}$} & Porosity, \% \\
\cline { 2 - 3 } & Major phase & Miner phase & & \\
\hline $100 / 0$ & C-S-H (I) & - & 6691 & 8.9 \\
\hline $80 / 20$ & tobermorite & - & 5983 & 9.7 \\
\hline $60 / 40$ & tobermorite & geopolymer & 5271 & 10.1 \\
\hline $40 / 60$ & geopolymer & tobermorite & 4790 & 11.5 \\
\hline $20 / 80$ & geopolymer & tobermorite & 789 & 45.6 \\
\hline
\end{tabular}


Table 4. Comparison of properties for representative self-degradable slag/Class C fly ash $(\mathrm{S} / \mathrm{C})$ and slag/Class F fly ash (S/F) sealing systems.

\begin{tabular}{|c|c|c|c|c|c|c|}
\hline Formula & $\begin{array}{l}\text { Initial } \\
\text { setting } \\
\text { time at } \\
85^{\circ} \mathrm{C} \text {, min }\end{array}$ & $\begin{array}{l}\text { Compressive } \\
\text { strength, psi, } \\
\text { after } 200^{\circ} \mathrm{C} \\
\text { autoclave }\end{array}$ & $\begin{array}{l}\text { Porosity, \%, } \\
\text { after } 200^{\circ} \mathrm{C} \\
\text { autoclave }\end{array}$ & $\begin{array}{l}\text { Phase } \\
\text { composition } \\
\text { after } 200^{\circ} \mathrm{C} \\
\text { autoclave }\end{array}$ & $\begin{array}{l}\text { Exothermic } \\
\text { temperature } \\
\text { for } 200^{\circ} \mathrm{C} \text { - } \\
\text { heated } \\
\text { sealers, }{ }^{\circ} \mathrm{C}\end{array}$ & $\begin{array}{l}\text { Exothermic } \\
\text { temperature } \\
\text { for } 250^{\circ} \mathrm{C}- \\
\text { heated } \\
\text { sealers, }{ }^{\circ} \mathrm{C}\end{array}$ \\
\hline $\begin{array}{l}20 / 80 \mathrm{~S} / \mathrm{C} \\
\text { ratio }\end{array}$ & $\sim 60$ & 2187 & 36.5 & $\begin{array}{l}\text { tobermorite, } \\
\text { C-S-H (I) }\end{array}$ & 41.5 & Unknown \\
\hline $\begin{array}{l}80 / 20 \mathrm{~S} / \mathrm{F} \\
\text { ratio }\end{array}$ & $\sim 60$ & 5983 & 9.7 & tobermorite & 40.0 & 42.7 \\
\hline $\begin{array}{l}60 / 40 \mathrm{~S} / \mathrm{F} \\
\text { ratio }\end{array}$ & $\sim 150$ & 5271 & 10.1 & $\begin{array}{l}\text { tobermorite, } \\
\text { geopolymer }\end{array}$ & 31.0 & 40.9 \\
\hline
\end{tabular}



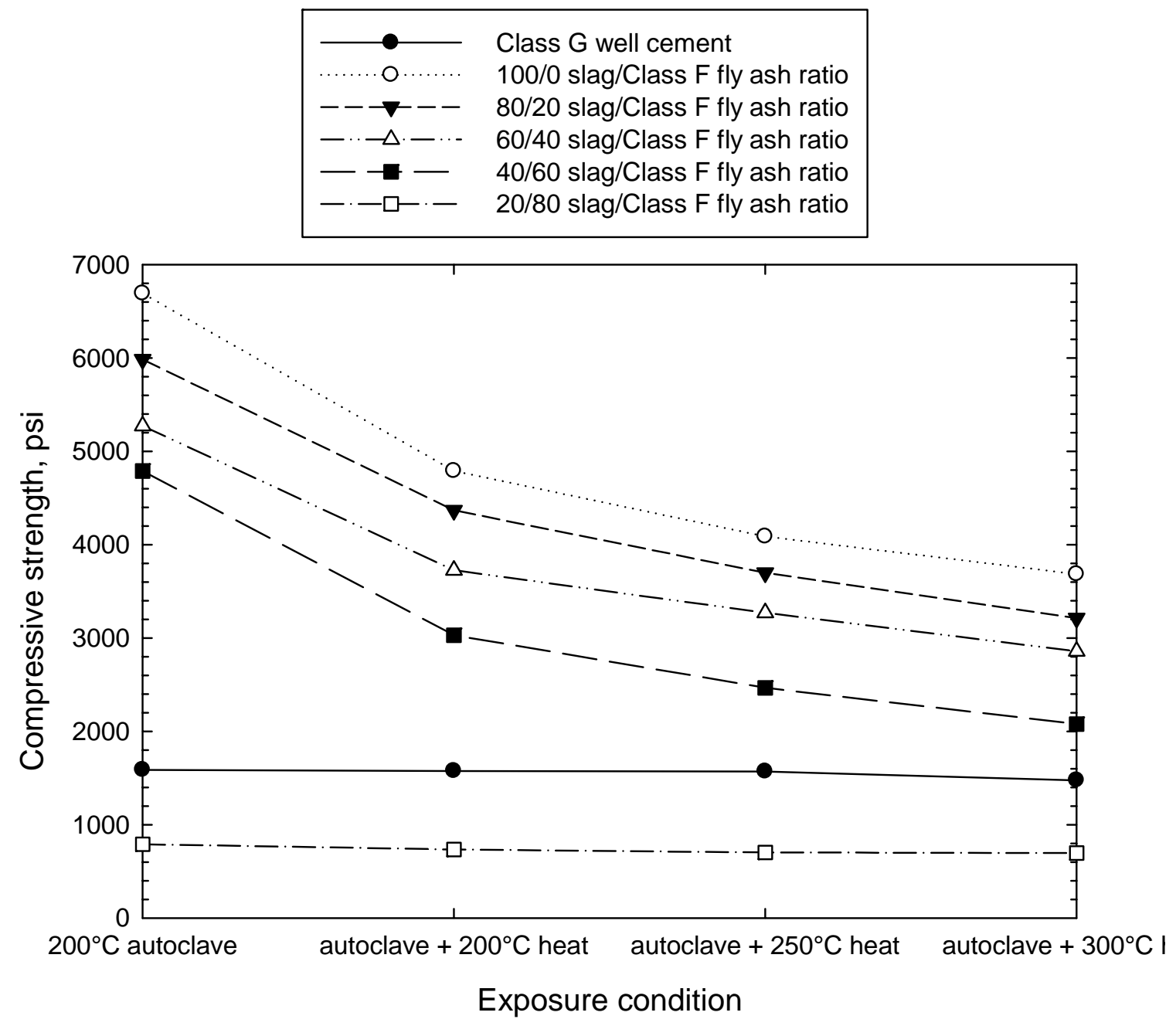

Figure 1. Compressive strength of the specimens made with 100/0, 80/20, 60/40, 40/60, and 20/80 ratios and Class $\mathrm{G}$ well cement after exposure in four different thermal environments. 

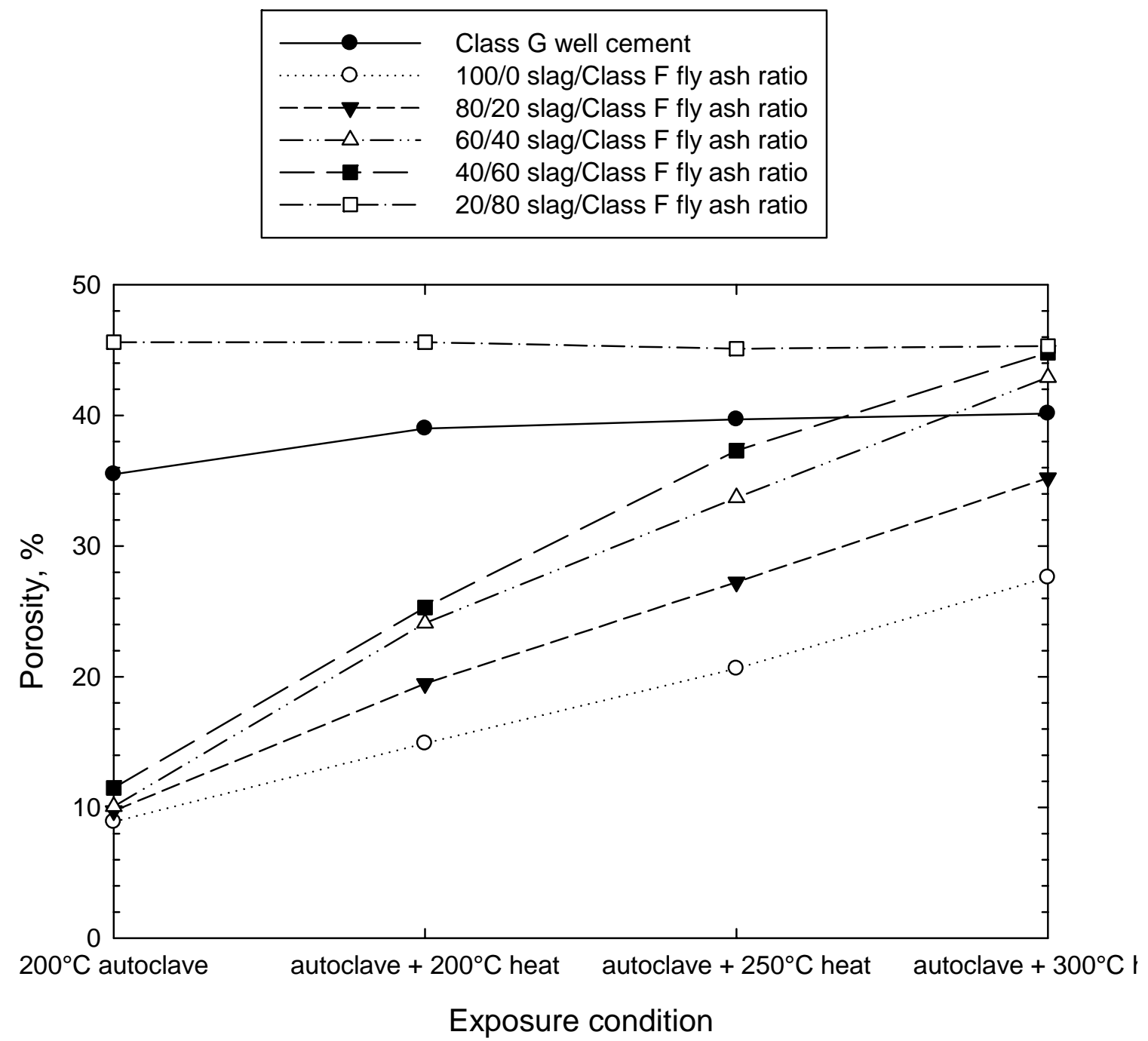

Figure 2. Changes in porosity of $200^{\circ} \mathrm{C}$-autoclaved $100 / 0,80 / 20,60 / 40,40 / 60$, and 20/80 ratio specimens as a function of heating temperature. 


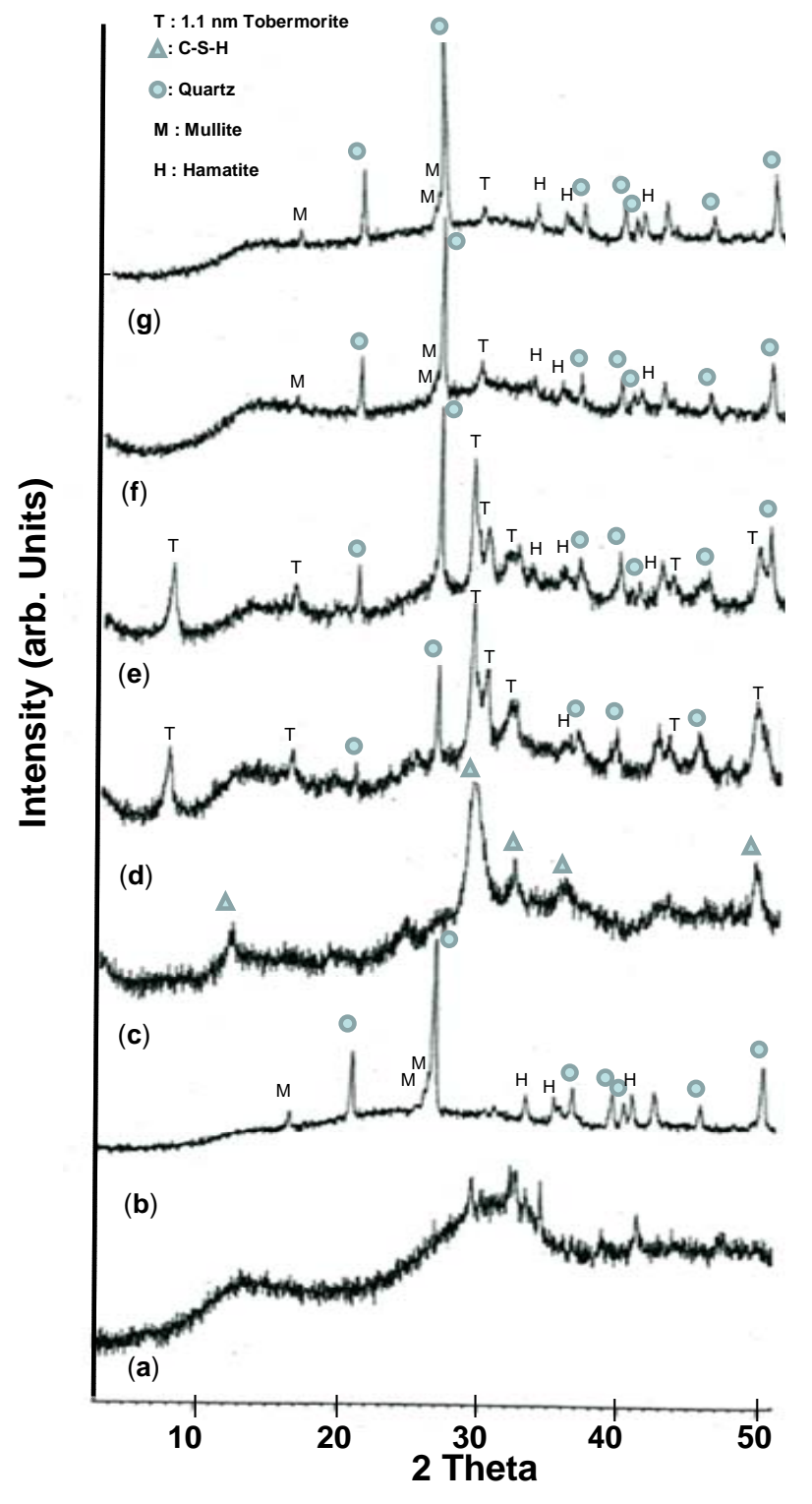

Figure 3. XRD patterns for slag (a), Class F fly ash (b), $200^{\circ} \mathrm{C}$-autoclaved $100 / 0$ (c), 80/20 (d), 60/40 (e), 40/60 (f), and 20/80 (g) slag/Class F fly ash ratio specimens. 

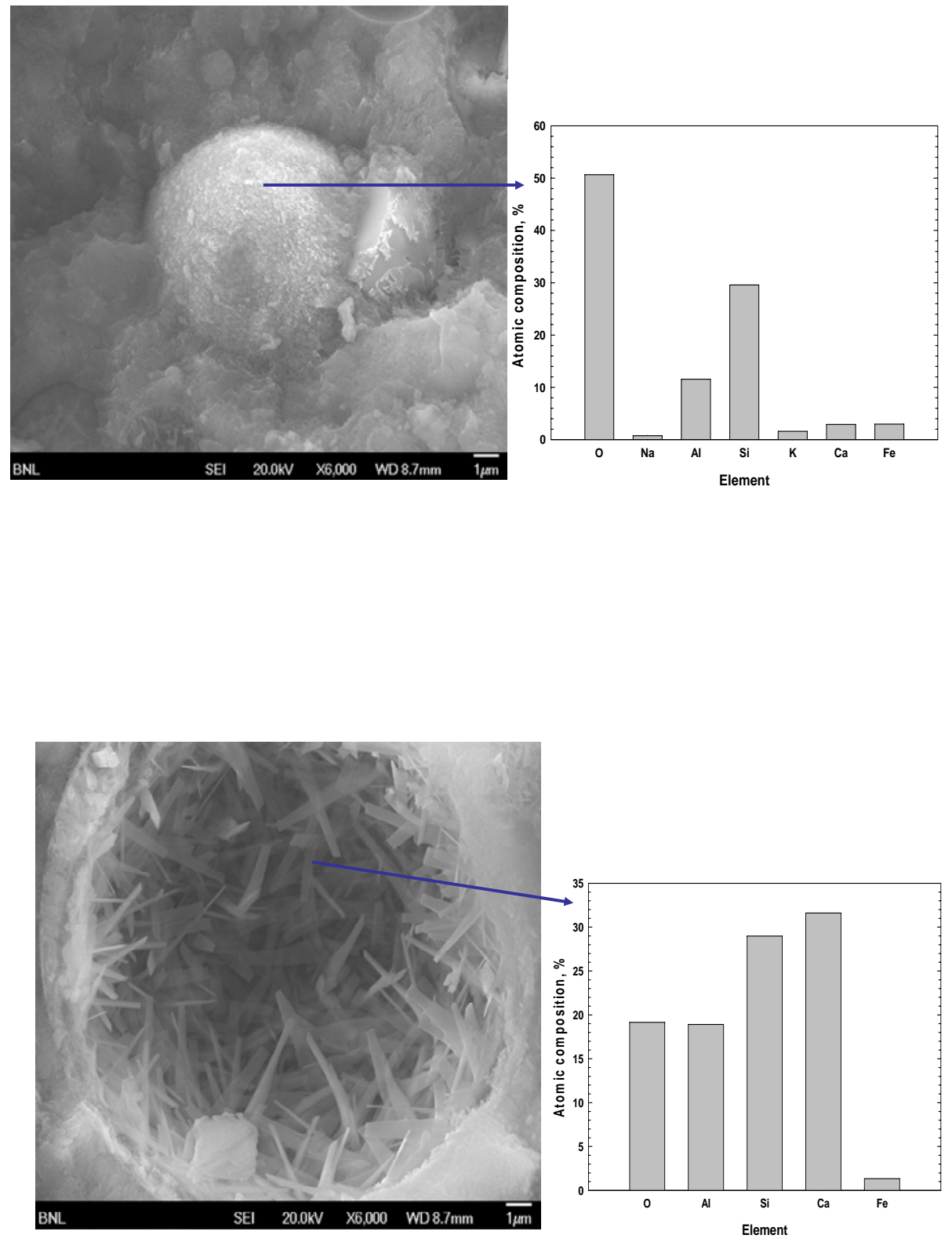

Figure 4. SEM images coupled with EDX atomic compositions for non-reacted Class F fly ash sphere (top) remained and aluminum-substituted $1.1 \mathrm{~nm}$ tobermorite crystal (bottom) formed in $200^{\circ} \mathrm{C}$-autoclaved $60 / 40$ slag/Class $\mathrm{F}$ fly ash ratio specimen. 


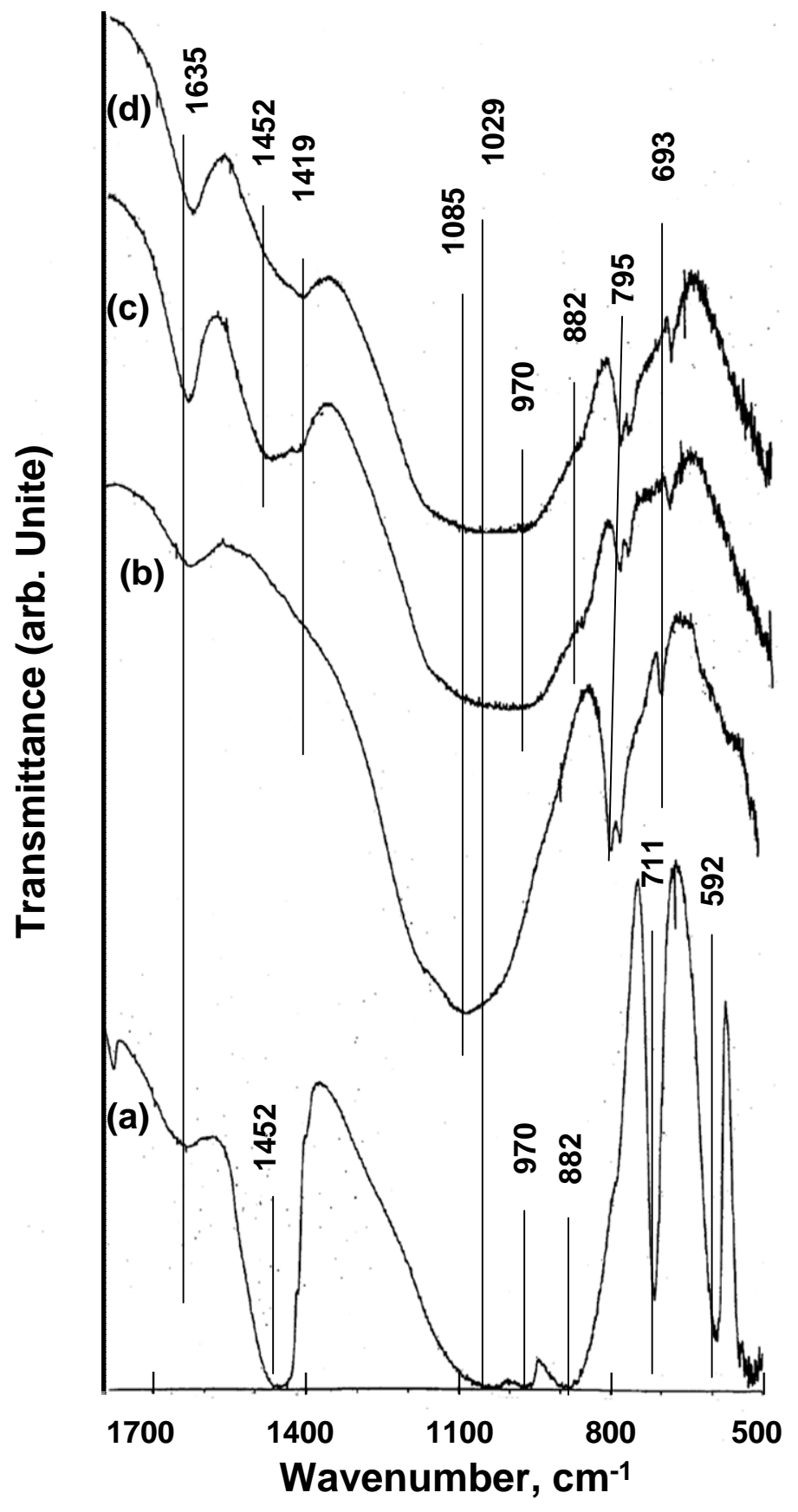

Figure 5. FT-IR spectra for "as-received" sodium silicate (a) and Class F fly ash (b), and $200^{\circ} \mathrm{C}$-autoclaved $40 / 60$ (c) and 20/80 (d) ratio specimens. 
Step 1. Dissolution of aluminum silicate reactants in alkali medium

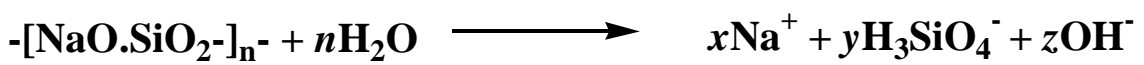
sodium silicate

$$
3 \mathrm{Al}_{2} \mathrm{O}_{3} \cdot 2 \mathrm{SiO}_{2}+\mathrm{zOH}^{-} \longrightarrow x \mathrm{Al}(\mathrm{OH})_{4}^{-}+y \mathrm{H}_{3} \mathrm{SiO}_{4}^{-}
$$

mullite in fly ash

Step 2. Reaction between these dissociated ionic species

$$
\begin{aligned}
& \text { OH OH OH } \\
& \mathrm{Na}^{+}+\mathrm{H}_{3} \mathrm{SiO}_{4}{ }^{-}+2 \mathrm{Al}(\mathrm{OH})_{4}{ }^{-} \longrightarrow \mathrm{Na}^{+}-\mathrm{O}-\mathrm{Al}-\mathrm{O}-\mathrm{Si}-\mathrm{O}-\mathrm{Al}-\mathrm{OH}+3 \mathrm{H}_{2} \mathrm{O} \\
& \text { Pre-geoplymer }
\end{aligned}
$$

Step 3. Self-polycondensation between pre-polymers

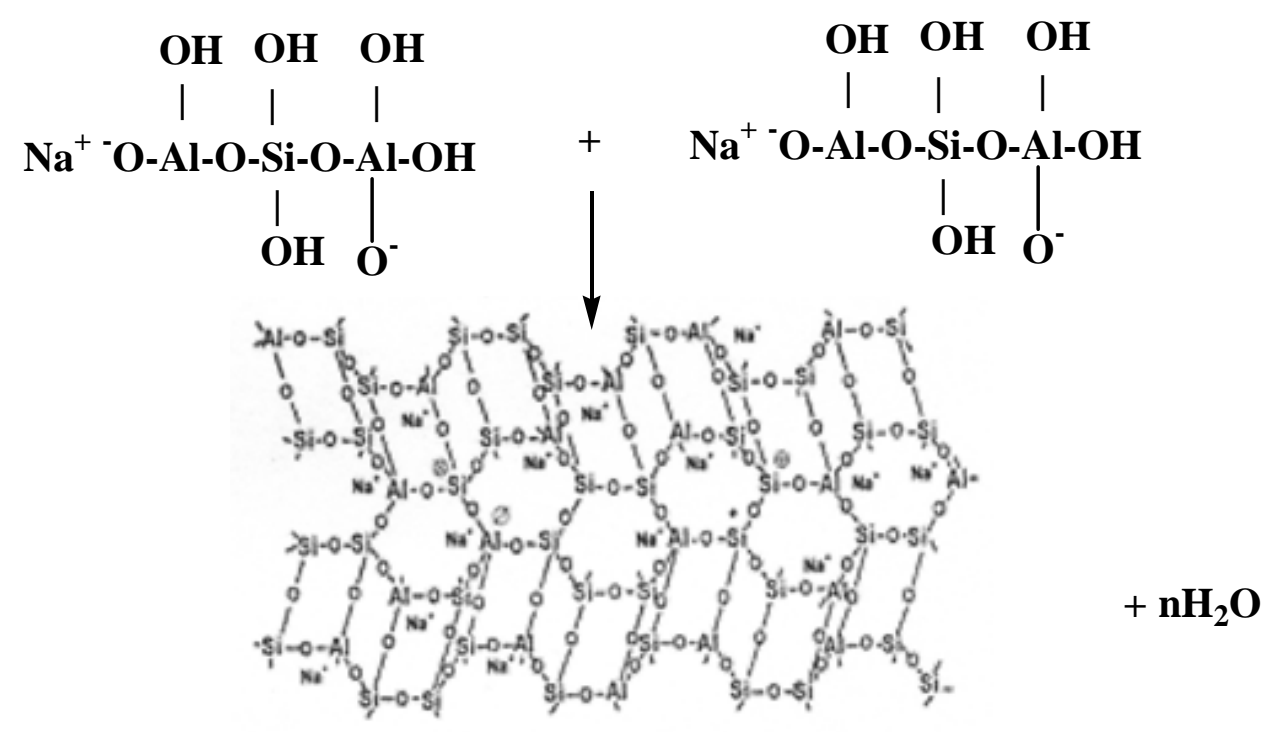

\section{Geopolymer}

Figure 6. Formation of geopolymer assembled through three-step reaction pathways. 


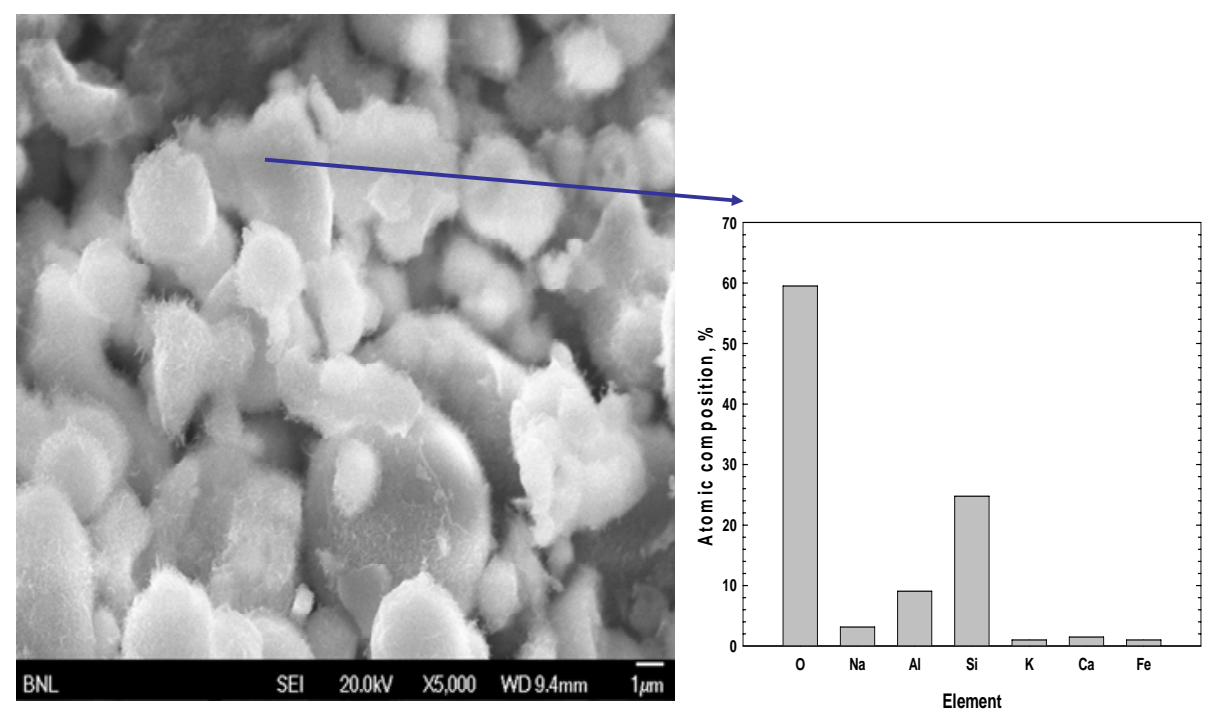

Figure 7. Microstructure and atomic composition of amorphous geopolymer formed in $200^{\circ} \mathrm{C}$-autoclaved $40 / 60 \mathrm{slag} / \mathrm{Class} \mathrm{F}$ fly ash ratio specimen. 


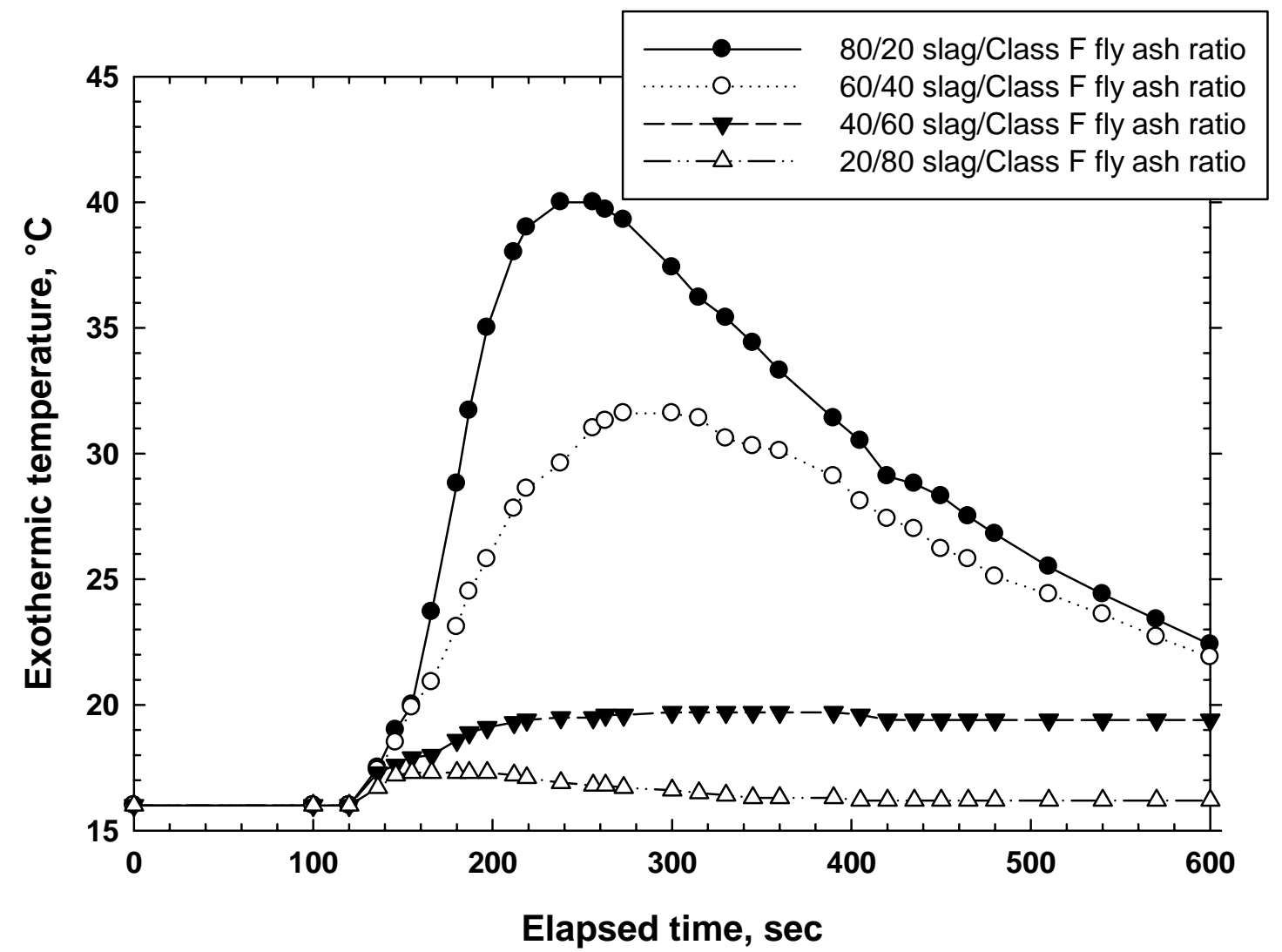

Figure 8. In-situ exothermic temperature vs. elapsed time for autoclaved 80/20, 60/40, $40 / 60$, and $20 / 80 \mathrm{slag} / \mathrm{Class} \mathrm{F}$ fly ash ratio specimens heated at $200^{\circ} \mathrm{C}$ after beginning impregnation with water. 

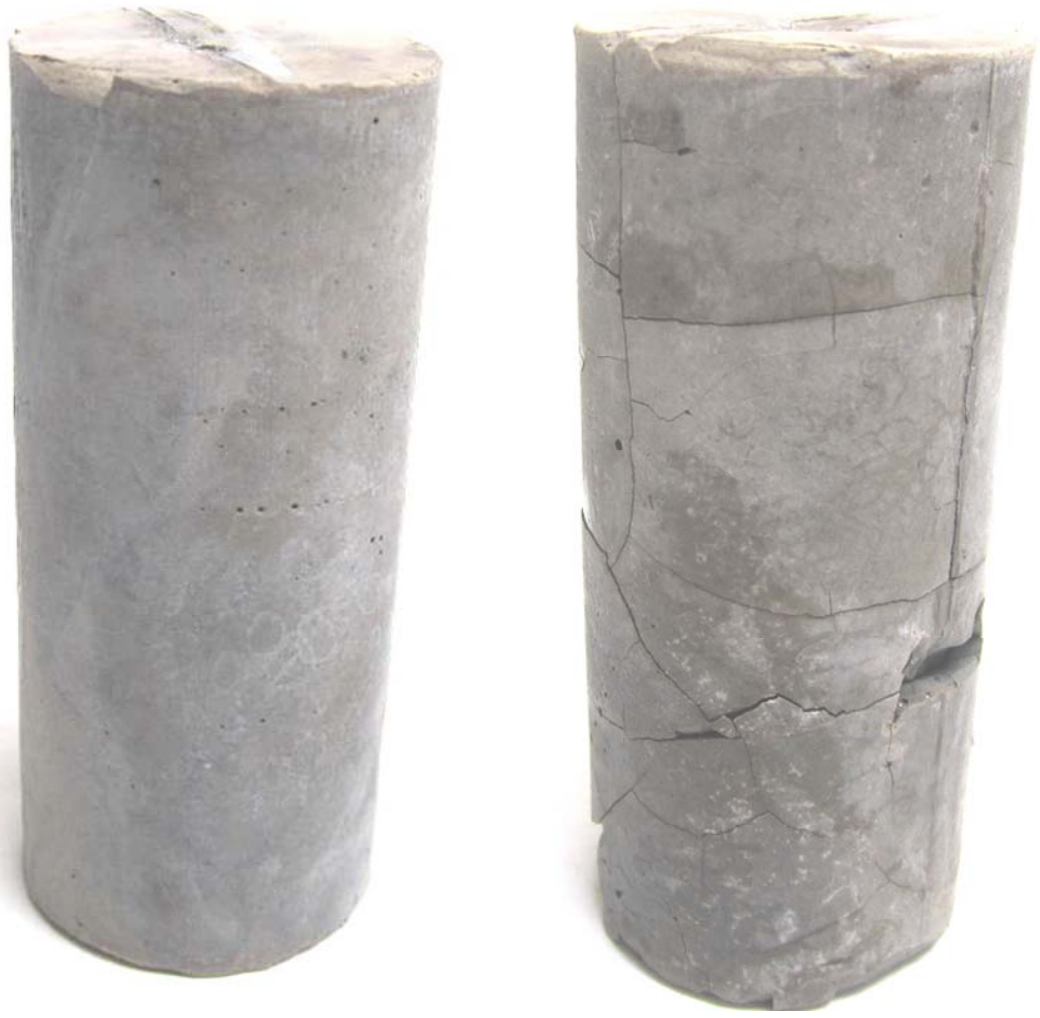

Figure 9. Appearance of $200^{\circ} \mathrm{C}$-heated $60 / 40$ slag/Class $\mathrm{F}$ fly ash ratio specimens before (left) and after (right) water impregnation. 

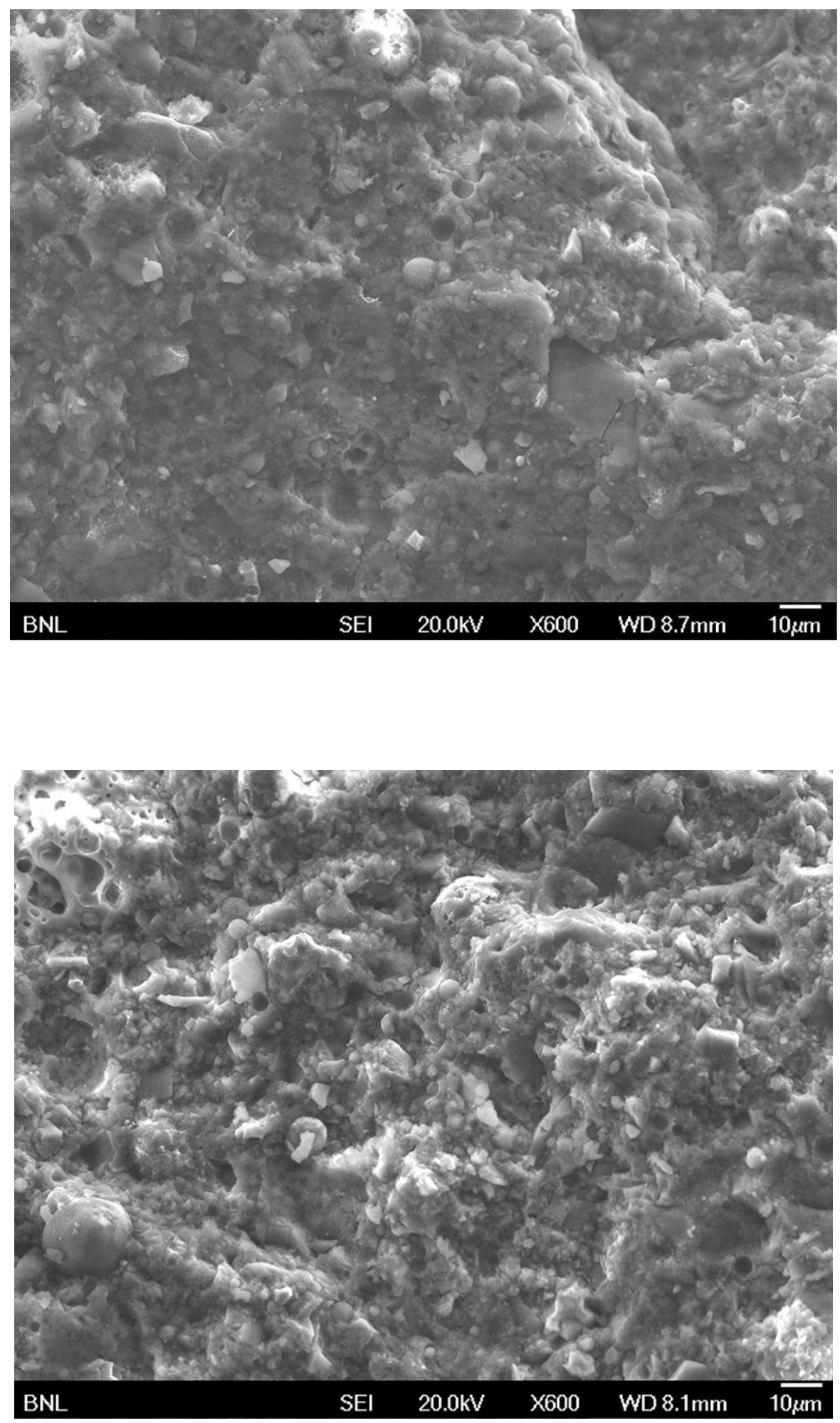

Figure 10. SEM images for fractured surfaces of 60/40 slag/Class F fly ash ratio specimens before (top) and after (bottom) self-degradation. 


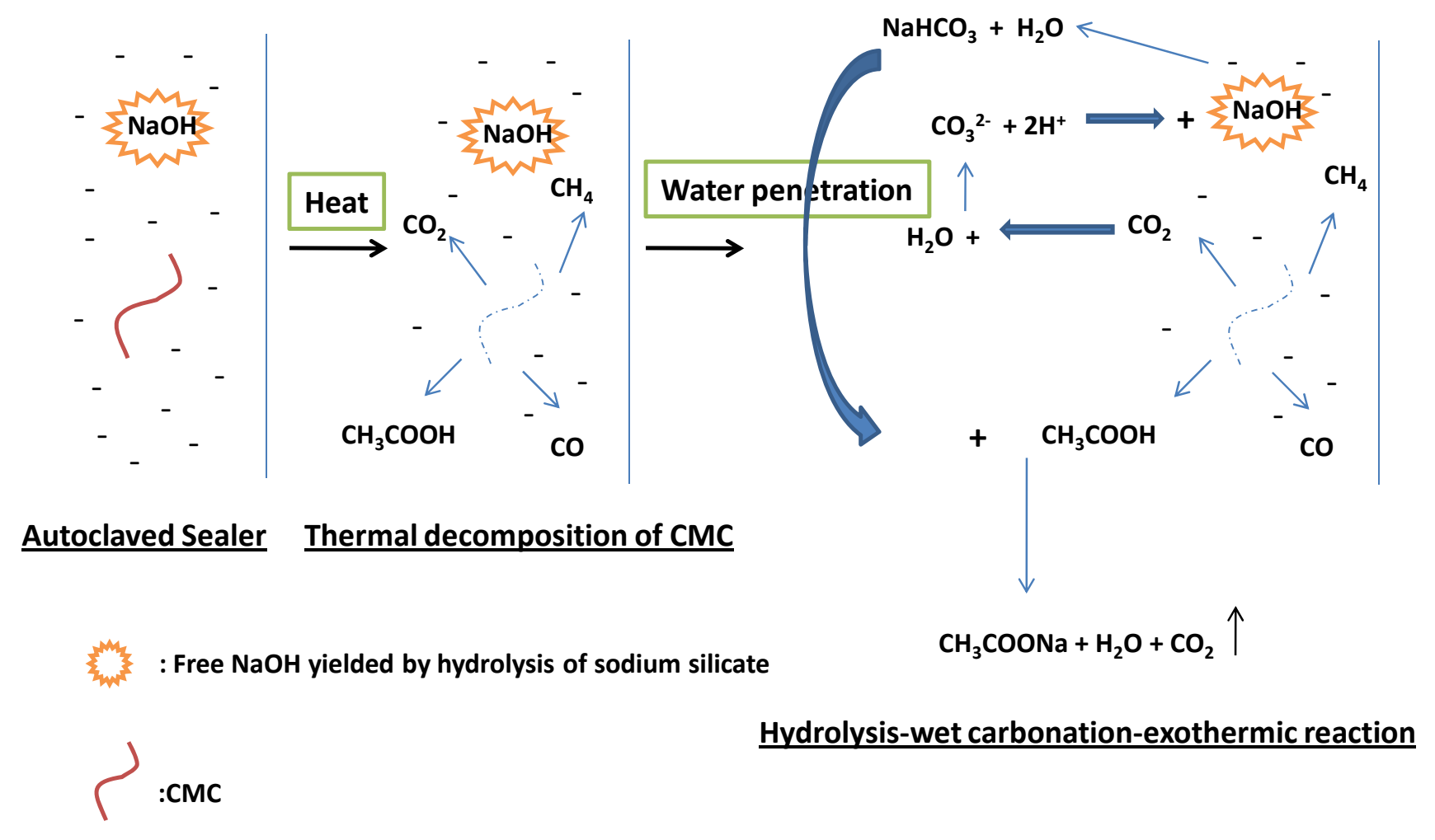

Figure 11. Self-degradation scheme of heated CMC-containing sodium silicate-activated pozzolan cementitious materials after contact with water. 


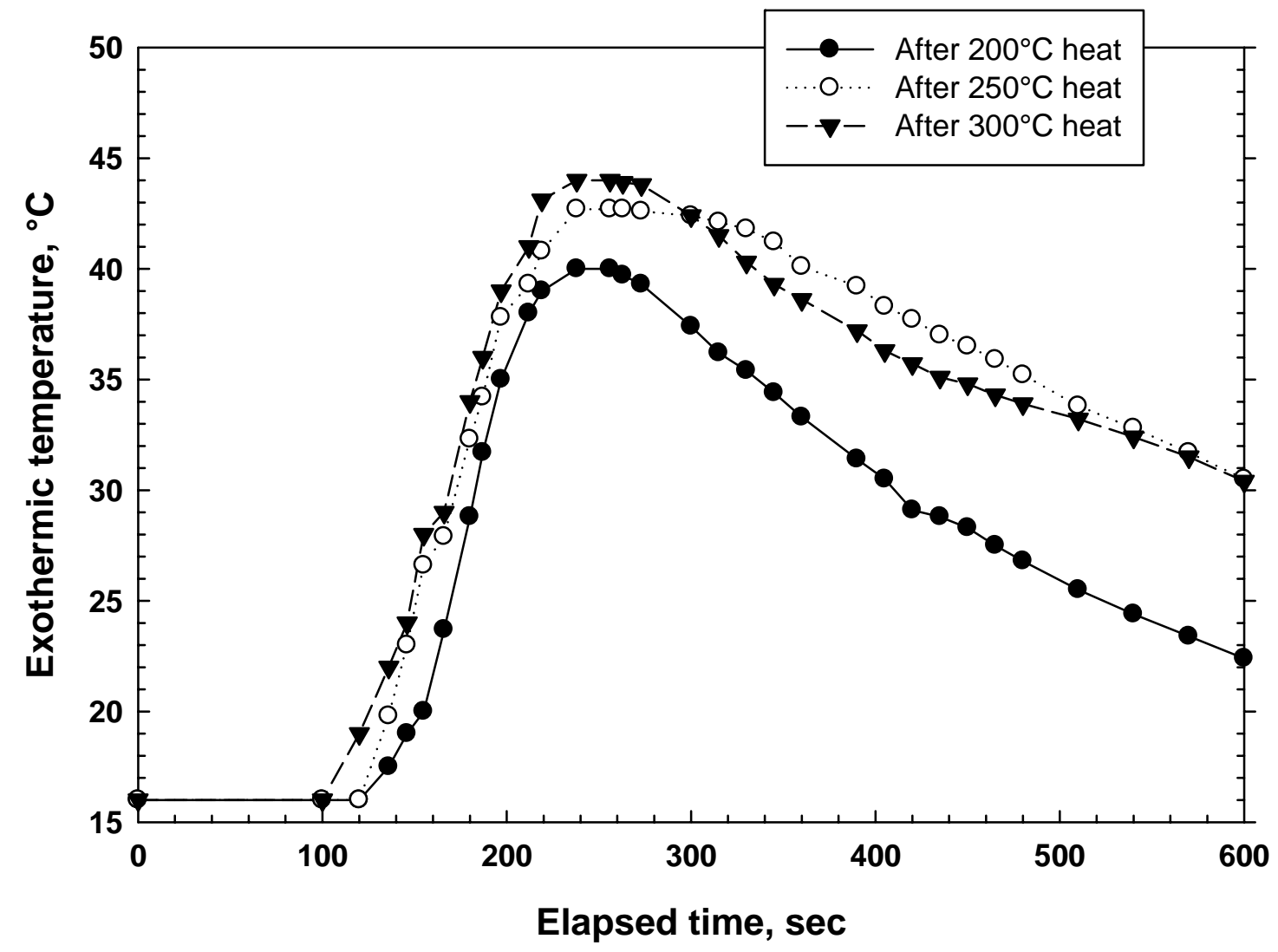

Figure 12. Comparison of exothermic peak temperatures for $200^{\circ}-, 250^{\circ}$-, and $300^{\circ} \mathrm{C}$ heated 80/20 slag/Class F fly ash ratio specimens after water impregnation. 


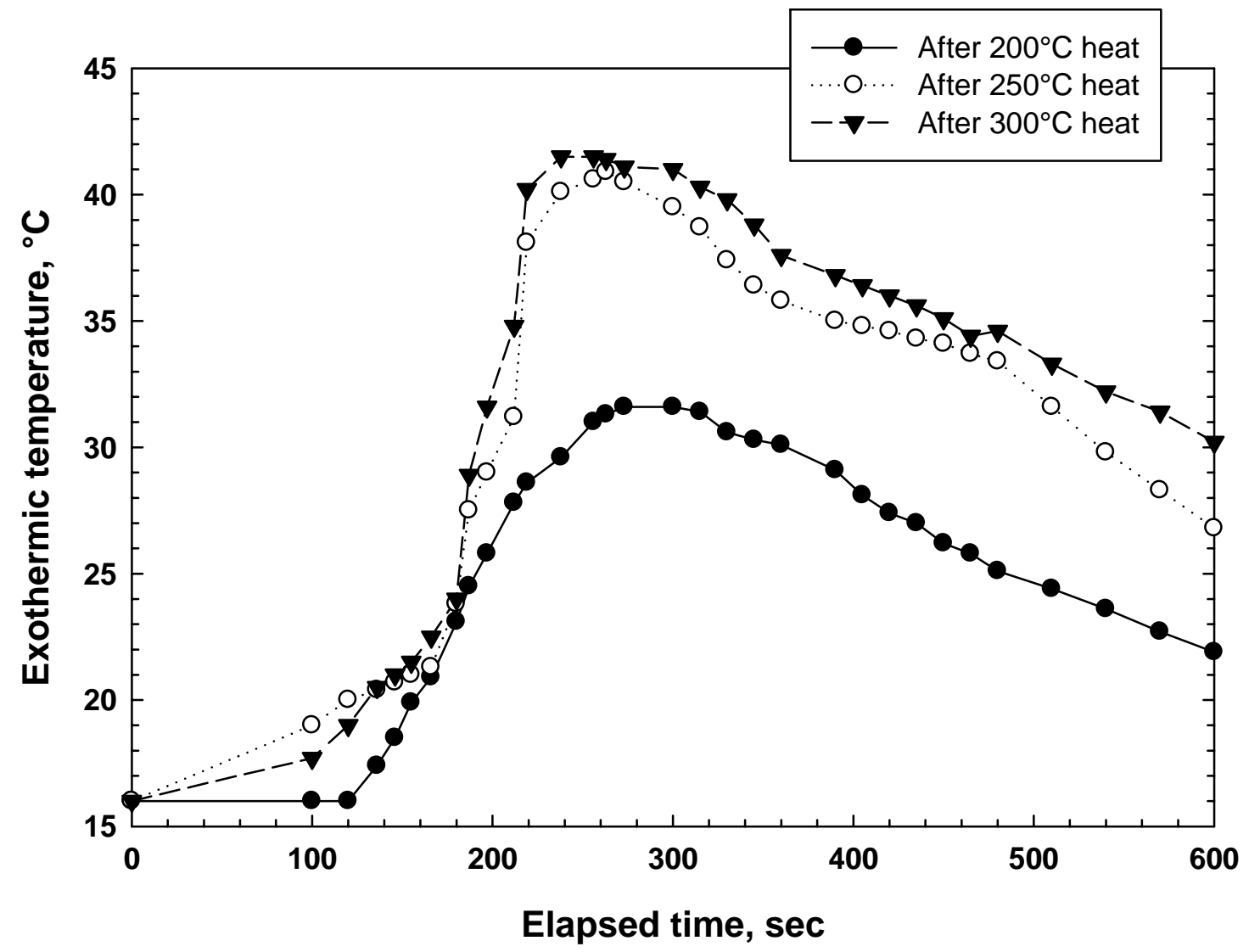

Figure 13 . Exothermic peak temperatures of $200^{\circ}$-, $250^{\circ}$-, and $300^{\circ} \mathrm{C}$-heated $60 / 40$ slag/Class F fly ash ratio specimens after water impregnation. 